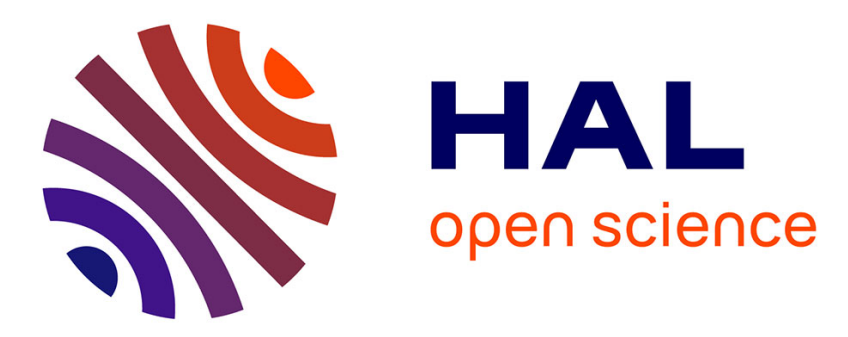

\title{
Tumor-Derived TGF $\beta$ Alters the Ability of Plasmacytoid Dendritic Cells to Respond to Innate Immune Signaling.
}

Mariana Terra, Marine Oberkampf, Catherine Fayolle, Pierre Rosenbaum, Camille Guillerey, Gilles Dadaglio, Claude Leclerc

\section{- To cite this version:}

Mariana Terra, Marine Oberkampf, Catherine Fayolle, Pierre Rosenbaum, Camille Guillerey, et al.. Tumor-Derived TGF $\beta$ Alters the Ability of Plasmacytoid Dendritic Cells to Respond to Innate Immune Signaling.. Cancer Research, 2018, 78 (11), pp.3014-3026. 10.1158/0008-5472.CAN-17-2719 . pasteur-01942405

\section{HAL Id: pasteur-01942405}

https://hal-pasteur.archives-ouvertes.fr/pasteur-01942405

Submitted on 4 Dec 2018

HAL is a multi-disciplinary open access archive for the deposit and dissemination of scientific research documents, whether they are published or not. The documents may come from teaching and research institutions in France or abroad, or from public or private research centers.
L'archive ouverte pluridisciplinaire HAL, est destinée au dépôt et à la diffusion de documents scientifiques de niveau recherche, publiés ou non, émanant des établissements d'enseignement et de recherche français ou étrangers, des laboratoires publics ou privés.

\section{(1)(1) $\$(0)$}

Distributed under a Creative Commons Attribution - NonCommercial - ShareAlikel 4.0 
Tumor-derived TGF- $\beta$ alters the ability of plasmacytoid dendritic cells to respond to innate immune signaling

Authors : Mariana Terra ${ }^{1,2,3}$, Marine Oberkampf ${ }^{1,2}$, Catherine Fayolle ${ }^{1,2}$, Pierre Rosenbaum $^{1,2}$, Camille Guillerey ${ }^{1,2,4}$, Gilles Dadaglio ${ }^{1,2,5}$ and Claude Leclerc ${ }^{1,2,5}$

\section{Affiliations:}

${ }^{1}$ Institut Pasteur, Unité de Régulation Immunitaire et Vaccinologie, Equipe Labellisée Ligue Contre le Cancer, 75015 Paris, France. ${ }^{2}$ INSERM U1041, 75015 Paris, France. ${ }^{3}$ Université Paris-Diderot, Sorbonne Paris Cité, 75205 Paris, France. ${ }^{4}$ Present address: Immunology of Cancer and Infection Laboratory, QIMR Berghofer Medical Research Institute, Herston, Queensland, Australia. ${ }^{5}$ Co-senior and corresponding authors

Running title: TGF- $\beta$ produced by tumor cells alters the functions of $\mathrm{pDCs}$

Keywords: Tumor, Plasmacytoid dendritic cells, Type I interferon, Transforming growth factor $\beta$, NK cells

Acknowledgements: This work was supported by the Ligue Nationale Contre le Cancer (Equipe Labellisée 2017). The research leading to these results has received funding from the People Programme (Marie Skłodowska-Curie Actions) of the European Union's Seventh Framework Programme FP7/2007-2013/ under REA grant agreement n³17057. 
Corresponding authors: Claude Leclerc, Institut Pasteur, 25 rue du Dr Roux, 75015 Paris,

France. Phone: 331456886 18, Fax: 331456885 40, E-mail: claude.leclerc@ pasteur.fr or

Gilles Dadaglio, Institut Pasteur, 25 rue du Dr Roux, 75015 Paris, France. Phone: 3314568

84 55, Fax: 331456885 40, E-mail: gilles.dadaglio@ pasteur.fr

Disclosure of potential conflicts of interest: The authors have no conflicting interests.

Word counts: 4808; abstract: 214; tables: 0; figures: 6; references: 49 


\begin{abstract}
A growing number of observations has suggested that plasmacytoid dendritic cells (pDC) play a critical role in tumor biology. In patients, infiltration of tumors by pDC generally correlates with a poor prognosis, suggesting that $\mathrm{pDC}$ may play an important role in the host-tumor relationship. Here we analyze the influence of $\mathrm{pDC}$ in solid tumor development using two different tumor models: TC-1 and B16-OVA. Phenotypic and functional gene profiling analysis of tumor-associated pDC showed that the tumor microenvironment affected their activation status and ability to produce cytokines and chemokines. In addition, tumor cells secreted factors that inhibit the ability of $\mathrm{pDC}$ to produce type I IFN. Among the various cytokines and chemokines produced by the tumor cells, we demonstrate that TGF- $\beta$ is the main factor responsible for this inhibition. Using a mouse model deficient for pDCs, we also show that pDCs promote TC-1 tumor growth and that NK cells and regulatory $\mathrm{T}$ cells are involved in the protumoral effect of pDCs. Overall, our results evidence the crosstalk among pDCs, NK and regulatory $\mathrm{T}$ cells in the promotion of tumor growth and their role in the development of anti-tumor immune responses.
\end{abstract}

SIGNIFICANCE: Findings highlight the importance of pDC in the cross-talk between tumor cells and the immune system. 


\section{INTRODUCTION}

Plasmacytoid dendritic cells (pDCs) contribute to antiviral immunity by their ability to produce a high amount of type I interferon (IFN-I) in response to Toll-like Receptor (TLR) 7 or 9 stimulation. In addition, upon activation, pDCs secrete a large panel of cytokines, such as TNF- $\alpha$, IL-6 and IL-12 (1-4), as well as chemokines, including CCL3, CCL4, CCL5, CXCL9 and CXCL10 $(5,6)$. pDCs induce the migration of innate effector cells, such as monocytes and macrophages, cDCs, NK and NKT cells (6-9), and activate these cells. In addition, activated pDCs can elicit adaptive immune responses through their capacity to present antigen to CD4 ${ }^{+}$ (10) and $\mathrm{CD}^{+} \mathrm{T}$ cells $(11,12)$.

pDCs are also endowed with regulatory functions (13), such as the induction and/or maintenance of peripheral tolerance mediated by their ability to promote $\mathrm{CD}^{+} \mathrm{FoxP}^{+}$Treg responses and to suppress immune responses to inhaled allergens (14), food antigens (15) and solid grafts (16). Because of their pleiotropic role, pDCs play an important role in noninfectious pathologies, such as autoimmune and inflammatory diseases, due to their uncontrolled production of IFN-I following chronic activation.

A growing number of observations has suggested that pDCs could also be implicated in cancer. Indeed, pDCs are recruited into solid tumors, both in human patients (17-22) and murine models (23), and pDC accumulation generally correlates with a poor clinical outcome. Tumor-associated (TA)-pDCs often exhibit an immature phenotype (24) and are poor producers of IFN-I and pro-inflammatory cytokines and chemokines in response to TLR stimulation $(18,24)$. TA-pDCs could also contribute to the establishment of an immunosuppressive tumor microenvironment by inducing the expansion of Treg through the expression of IDO or ICOS-L $(19,20,24,25)$. 
However, when activated, pDCs could generate efficient anti-tumor immune responses that would contribute to tumor regression. Indeed, the injection of activated pDCs loaded with tumor-associated peptides into melanoma patients leads to protective $\mathrm{CD}^{+}{ }^{+}$and $\mathrm{CD} 8^{+} \mathrm{T}$-cell responses (26). Furthermore, the intratumoral administration of a TLR-7 ligand results in the activation of tumor-infiltrating pDCs, associated with a potent anti-tumot effect (23). TLRstimulated pDCs mediate tumor killing through the expression of TRAIL and granzyme B, as well as through the activation of NK cells (27). Thus, pDCs represent an attractive target for the development of new anti-cancer immunotherapies to improve anti-tumoral immune responses.

In the present study, to understand the impact of pDCs on tumor development, we first analyzed the phenotype and functions of tumor-associated pDCs (TA-pDCs), at various stages of the development of two different mouse tumor models. Our results show that pDCs are recruited into the tumor in both models and exhibit a distinct activation and gene expression profile compared with pDCs purified from the spleen of naïve mice. These results suggest that the tumor microenvironment modulates the phenotype and function of TA-pDCs. In addition, we demonstrate that tumor cells secrete various cytokines and chemokines, which, inside the tumor microenvironment, strongly suppress the capacity of pDCs to produce IFN-I following TLR-9 stimulation. Among the soluble factors present in the tumor microenvironment, we identified TGF- $\beta$ as the main factor mediating this inhibition. Finally, using a mouse model deficient for pDCs, we show that pDCs promote tumor growth through a cross-talk with NK and regulatory $\mathrm{T}$ cells (Tregs). 


\section{MATERIALS AND METHODS}

\section{Mice}

Specific pathogen-free 5- to 6-week-old female C57BL/6 mice were purchased from Charles River. $\mathrm{IK}^{+/+} \mathrm{Rag}^{-/-}(28)$ and $\mathrm{IK}^{\mathrm{L} / \mathrm{L}} \mathrm{Rag}^{-/-}$mice were bred at the Institut Pasteur animal facilities. Foxp3-GFP knockin mice (29) on a C57BL/6J background were kindly given by B. Malissen (Centre d'Immunologie de Marseille-Luminy, Marseille, France). All the mouse strains were kept at the Institut Pasteur animal facilities under pathogen-free conditions and were used between 6 and 12 weeks old.

Studies using mice were validated by the CETEA ethics committee number 89 (Institut Pasteur, Paris, France) and by the French Ministry of Research (MESR 00540.03).

\section{Preparation of tumor conditioned medium (TCM) and tumor cells supernatants}

TC-1 and B16-OVA tumor cells were injected into C57BL/6 mice, and 20 - 35 days later, the tumors were collected and cut into equal-sized pieces of approximately $5 \mathrm{~mm}^{3}$. Each tumor piece was immersed for 24 or 72 hours in $2 \mathrm{~mL}$ of complete RPMI. The supernatants containing the tumor secretions were then collected, centrifuged and filtered.

The supernatants of TC-1 and B16-OVA tumor cells were collected, centrifuged and filtered when the cells were confluent.

Tumor TCM and supernatants were used either pure or diluted $1 / 2$ in complete medium, as detailed in the figure legends.

\section{Sample processing and cell isolation}

The lymph nodes were harvested, mechanically disrupted and filtered with $100-\mu \mathrm{m}$ mesh filters to obtain single-cell suspensions. The spleens were harvested, treated with collagenase type IV (1 mg/mL; Life Technologies) and DNAse I (50 $\mu \mathrm{g} / \mathrm{mL}$, Roche). The splenocytes were then treated with Ammonium-Chloride-Potassium (ACK) buffer (BioWhittaker/Lonza). 
The tumors were harvested and dissociated using the gentleMACS dissociator (Miltenyi Biotec) with collagenase type IV $(1 \mathrm{mg} / \mathrm{mL})$ and DNAse I $(50 \mu \mathrm{g} / \mathrm{mL})$ and then were treated with ACK buffer.

\section{pDC purification}

pDCs were purified either by magnetic selection or FACS Aria (BD Life Sciences, Le Pont de Claix, France) sorting. For the magnetic pDC purification, splenocytes were depleted from $\mathrm{CD}_{11 \mathrm{~b}^{+}}$and $\mathrm{CD} 19^{+}$cells using MACS-anti-CD11b and -anti-CD19 microbeads before the positive selection of $\mathrm{PDCA}^{+}$cells by AutoMACS or using the Plasmacytoid Dendritic Cell Isolation Kit from Miltenyi. For the FACS-sorted pDCs, magnetic purified pDCs were stained with anti-CD11c, anti-B220 and anti-PDCA1 antibodies, and the $\mathrm{CD} 11 \mathrm{c}^{\text {low }} \mathrm{B} 220^{+} \mathrm{PDCA}^{+}$fraction was sorted using a FACS Aria III.

\section{Quantification of cytokines and chemokines}

IFN- $\alpha$ was dosed by ELISA as previously described (6). In some experiments, IFN- $\alpha$ and IFN- $\beta$ were determined by the 2-plex Luminex assay (Affymetrix, Thermo Fisher Scientific). TGF- $\beta$ was quantified using the TGF- $\beta$ - 1 ELISA kit (Affymetrix). Other cytokines and chemokines were quantified using the 26-plex Luminex assays (Affymetrix). The data were acquired on a validated and calibrated Bio-Plex 200 system (Bio-Rad) and were analyzed using Bio-Plex Manager 6.0 software (Bio-Rad).

\section{In vivo blockade of anti-TGF- $\beta$}

$\mathrm{C} 57 \mathrm{BL} / 6, \mathrm{IK}^{\mathrm{L} / \mathrm{L}} \mathrm{Rag}^{-/-}$and $\mathrm{IK}^{+/+} \mathrm{Rag}^{-/-}$mice were grafted with $5 \times 10^{5} \mathrm{TC}-1$ cells at day 0 and were treated with i.p. injections of $500 \mu \mathrm{g}$ of anti-TGF- $\beta$ antibodies (clone 1D11.16.8 (30,31), BioXcell) or control isotype on day -1 and then three time a week for five weeks.

\section{Depletion of NK cells in vivo}


Mice were injected intraperitoneally with $200 \mu \mathrm{g}$ of anti-NK1.1 antibodies (clone PK136, BioXcell) or control isotype (clone C1.18.4, BioXcell) diluted in sterile PBS, one day before the tumor injection and then once a week for 5 weeks.

\section{Reconstitution of IK ${ }^{+/+} \mathrm{Rag}^{-/-}$and IK ${ }^{\mathrm{L} / \mathrm{L}} \mathrm{Rag}^{-/-}$mice with pDC-depleted splenocytes}

$\mathrm{IK}^{\mathrm{L} / \mathrm{L}} \mathrm{Rag}^{-/-}$and $\mathrm{IK}^{+/+} \mathrm{Rag}^{-/-}$mice were injected with 50-80 $10^{6}$ splenocytes from Foxp3-GFP mice previously depleted of pDCs by magnetic depletion and containing less than $0.002 \%$ of pDCs. Seven days later, mice were grafted with $5 \times 10^{5}$ TC- 1 cells and the tumor growth was followed every 2-3 days. At day 25, cell suspensions were prepared from tumors and analyzed by flow cytometry.

\section{Statistical Analysis}

Prism software (GraphPad Software, Inc.) was used to calculate the statistical significance for the differences in the particular measurements between the groups. Student's t-test and MannWhitney test were used. P values less than 0.05 were considered statistically significant. 


\section{RESULTS}

\section{Plasmacytoid dendritic cells infiltrate TC-1 and B16-OVA tumors}

To analyze the role of pDCs in tumors, $5 \times 10^{5}$ TC- 1 or $2.5 \times 10^{4}$ B16-OVA tumor cells were subcutaneously engrafted into C57BL/6 mice, and the tumor growth was followed (Fig. 1A). At different time points, the total number of live cells in the tumor, comprising both immune infiltrating cells and tumor cells, was determined (Fig. 1B). pDCs were characterized as $\mathrm{CD} 11 \mathrm{~b}^{-\mathrm{CD}} 11 \mathrm{c}^{\text {low }} \mathrm{B} 220^{+} \mathrm{CD} 317^{+}$cells (Supplementary Fig. S1A), and their percentages among hematopoietic $\left(\mathrm{CD} 45^{+}\right)$, as well as their total number in the tumors, were determined (Fig. 1C-D). The results indicated that pDCs infiltrated the tumors and represented $0.1-1 \%$ and $1-5 \%$ of $\mathrm{CD}^{+} 5^{+}$cells in TC-1 and B16-OVA tumors, respectively. The phenotype of tumor-associated pDCs (TA-pDCs) was then determined at various time points in TC-1- and B16-OVA-bearing mice (Fig. 1E and 1F, respectively). Compared with naïve splenic pDCs, the TA-pDCs upregulated the expression of CD69 and that of the costimulatory molecule CD86 at each time point, indicating that TA-pDCs were activated. Furthermore, in TC-1 tumors, these cells showed a higher expression of CD80 and MHC class I and II molecules. However, with the exception of $\mathrm{CD} 80$, the level of these molecules diminished during tumor growth. By contrast, in B16-OVA tumors, these molecules were slightly modified compared with splenic pDCs, indicating that TA-pDCs are less activated in the B16-OVA tumors. In both tumor models, the expression of PDC-TREM increased only at early time points, suggesting a role of IFN-I in the early stage of tumor growth. A similar conclusion was obtained following the comparison of the expression of activation markers by TA-pDCs to splenic pDCs from the same tumor-bearing mice. 
Finally, we showed that the expression of PDL-1 and ICOS-L in B16-OVA TA-pDCs and PDL-1 on TC-1 TA-pDCs was affected by the tumor environment, suggesting that pDCs could affect the T-cell response in the tumors.

It is noteworthy that the frequency of pDCs in the spleen and draining lymph node (DLN) of tumor-bearing mice was slightly modified (Supplementary Fig. S1B), and no significant change in the expression of the costimulatory, inhibitory and MHC molecules tested was observed compared with pDCs from the spleen of naïve mice (Supplementary Fig. S1C). Altogether, these data indicate that the tumor environment affected the activation of pDCs.

Plasmacytoid dendritic cells infiltrating the TC-1 and B16-OVA tumors exhibit a particular transcriptomic profile

We next analyzed the transcriptomic profile of TA-pDCs to assess the impact of the tumor environment on pDCs. Transcriptomic analysis was performed on pDCs purified from tumors (Supplementary Fig. S2A-B) using NanoString technology. We compared the expression of about 800 tumor-associated genes between TA-pDCs purified from TC-1 and B16-OVA tumor-bearing mice and pDCs purified from the spleen of naïve C57BL/6 mice. The hierarchical heat map clustering analysis performed using Qlucore software showed that TApDCs of both TC-1 and B16-OVA tumors exhibited a strikingly transcriptional gene modulation compared with splenic pDCs (Supplementary Fig. S3A). To compare more precisely how the tumor environment modulated the gene expression program of TA-pDCs, we identified the genes that were significantly induced or inhibited $(p<0.05)$ compared with control splenic pDCs, and we determined the overlaps between these genes. In total, we selected 79 genes upregulated and 44 genes downregulated in TC-1 TA-pDCs, and 67 genes upregulated and 48 genes downregulated in B16-OVA TA-pDCs (Supplementary Fig. S3B). In agreement with the phenotypical analysis of TA-pDCs, some genes were differentially 
expressed between pDCs infiltrating these two tumors. Indeed, only 29 genes $(24.8 \%$ of total upregulated genes) and 12 genes (15\% of total downregulated genes) of the pDCs infiltrating either TC-1 or B16-OVA tumors were upregulated or downregulated in the two models, respectively, suggesting that, despite some similarities, the TC-1 and B16-OVA specifictumor microenvironment differentially affected pDCs.

The pathway analysis and gene ontology enrichment of the selected genes were then performed using Ingenuity® Pathways Analysis software (Supplementary Fig. S3C). Among the most significant functions and pathways, the genes belonging to the activation of interferon regulatory factors (IRF) by the cytosolic pattern recognition receptor (PRR) pathway, interferon signaling, antigen presentation pathway, communication between innate and adaptive immune cells and crosstalk between DCs and NKs were upregulated, showing that pDCs were stimulated in the tumor environment.

We also analyzed the gene expression profile of pDCs purified from the spleen of TC-1 and B16-OVA tumor-bearing mice (Supplementary Fig. S3D). As observed for TA-pDCs, some genes were up or downregulated compared with pDCs purified from control mice (Supplementary Fig. S3E).

These results showed that the transcriptional program of pDCs from tumor-bearing mice depended on their localization, and their gene expression was affected at distant sites from the tumor, such as in the spleen.

\section{Purified tumor-associated plasmacytoid dendritic cells are functional}

To assess the functionality of TA-pDCs, we purified pDCs from TC-1 and B16-OVA tumors and analyzed their capacity to produce cytokines and chemokines after $\mathrm{CpG}$ stimulation in vitro using 2-plex and 26-plex Luminex assays (Supplementary Fig. S4A). These cells secreted IFN- $\alpha$, IFN- $\beta$, TNF- $\alpha$, MIP1- $\alpha$, MIP1- $\beta$, RANTES and Eotaxin (Supplementary 
Fig. S4B). TA-pDCs from TC-1 tumors secreted higher levels of these factors compared with pDCs from the spleens of naïve C57BL6/C mice. These results demonstrate that TA-pDCs were functional when removed from the tumor environment and could produce a high level of cytokines and chemokines after CpG stimulation.

\section{Soluble factors produced by tumor cells alter the phenotype of pDCs and their capacity to produce cytokines and chemokines upon activation}

Since our results suggest that tumor environment could affect the phenotype and functions of TA-pDCs, we then investigated the mechanisms responsible for these modifications. We first prepared tumor-conditioned medium (TCM) corresponding to the supernatant of culture of small pieces of TC-1 tumor excised from C57BL/6 mice. We then analyzed the ability of pDCs purified from the spleen of normal C57BL/6 and cultured with TCM to produce IFN- $\alpha$ upon $\mathrm{CpG}$ activation. Our results show that, in the presence of TCM, the production of IFN- $\alpha$ by pDCs was totally abolished (Fig. 2A) showing that soluble factors present in the TCM actively inhibited the production of IFN-I. Similar results were obtained with TCM prepared from B16-OVA tumors (Supplementary Fig. S5A-D).

To determine whether these factors were produced by the tumor cells or by stroma cells, similar experiments were performed in the presence of culture supernatants of either TC- 1 or B16-OVA cells. The production of IFN- $\alpha$ was also totally impaired in the presence of these supernatants demonstrating that inhibitory factors were produced by $\mathrm{TC}-1$ and B16-OVA tumor cells (Fig. 2A). Furthermore, we showed that this inhibitory effect was not restricted to the production of IFN- $\alpha$ since, in the presence of TCM and TC-1 and B16-OVA supernatants, the capacity of CpG-activated pDCs to produce IFN- $\beta$, TNF- $\alpha$, MIP1- $\alpha$, MIP1- $\beta$, and Eotaxin was strongly affected (Fig. 2B). 
We then analyzed the effect of TCM or tumor supernatants on the expression of activation markers by pDCs (Fig. 2C and Supplementary Fig. S5B) and demonstrated that, in the presence of TC-1 or B16-OVA TCM, CpG failed to induce a significant upregulation of these activation markers. An inhibitory effect on the expression of some of these markers, but not of CD69, was also observed after incubation of pDCs with TC-1 or B16-OVA supernatants. These results suggested that pDCs could not be fully activated by $\mathrm{CpG}$ in the presence of these tumoral factors.

pDCs incubated for 4 hours with either TC-1 or B16-OVA TCM, and then washed before stimulation with $\mathrm{CpG}$, remained unable to produce IFN- $\alpha$ and to maturate showing the lack of reversibility of these inhibitory effects (Supplementary Fig. S6A-B).

Altogether these results demonstrate that the tumor environment strongly affects the capacity of pDCs to respond to innate stimulation.

TGF- $\beta$ secreted by TC- 1 and B16-OVA tumor cells suppresses the production of IFN- $\alpha$ by plasmacytoid dendritic cells stimulated by CpG

To characterize the soluble factors produced by tumor cells that could affect pDC functions, we then analyzed the cytokines and chemokines present in the TC-1 and B16-OVA TCM and supernatants by the 26-plex Luminex assay (Fig. 3A and Supplementary Fig. S5C) or by ELISA (Fig. 3B, Supplementary Fig. S5D). Some cytokines, such as MIP-2 and Gro$\alpha$, were exclusively detected in TCM, suggesting that these factors were produced by stroma cells. In contrast, RANTES (CCL5), MCP-3 (CCl7), MCP-1 (CCl2), IP-10 (CXCL10), IL-6, and TGF- $\beta$ were detected in all samples, showing that these factors were directly produced by the TC-1 and B16-OVA tumor cells. Thus, these molecules might be potential candidates for the alteration of $\mathrm{pDC}$ functions induced by TCM and TC-1 or B16-OVA supernatants. 
We then tested the ability of purified pDCs to produce IFN- $\alpha$ upon $\mathrm{CpG}$ stimulation, when cultured in the presence of a mix of these recombinant cytokines/chemokines (Fig. 3C). This experiment clearly demonstrated that the mix of these recombinant molecules strongly reduced the production of IFN- $\alpha$ by pDCs. To assess which factors could be responsible for this suppressive effect, this experiment was repeated in the presence of individual cytokines or chemokines. IL-6, IP-10, MCP-1, MCP-3 and RANTES did not affect the production of IFN- $\alpha$ by pDCs when used either alone or in combination at $10 \mathrm{ng} / \mathrm{ml}$. By contrast, a strong inhibition of IFN- $\alpha$ production was observed in the presence of recombinant TGF- $\beta$, even at a dosage as low as $0.1 \mathrm{ng} / \mathrm{mL}$ (Fig. 3D-F), clearly demonstrating that TGF- $\beta$ played an important role in the inhibitory effect observed with TCM or tumor supernatants.

It should however be mentioned that lower doses of recombinant TGF- $\beta$, in the range of the amount detected in TCM or SUP, did not affect the pDC responses to TLR ligands. The bioactivity of this recombinant TGF- $\beta$ and of TCM or tumor supernatants, expressed per $\mathrm{pg} / \mathrm{ml}$, was however found comparable by using HEK-blue TGF- $\beta$ reporter cells, which allow the detection of bioactive TGF- $\beta$ by monitoring the activation of the TGF- $\beta$ / Smad pathway. It thus be suggested that TGF- $\beta$ acts in synergy with other factors produced in the tumor microenvironment. However, IL-6, IP-10, MCP-1, MCP-3 and RANTES added to various doses of TGF- $\beta$, did not increased the inhibitory effect of this cytokine on the production of IFN- $\alpha$ by pDCs (Fig. 3F).

This suppressive effect of TGF- $\beta$ did not only affect IFN- $\alpha$ production but also reduced the expression of CD69, MHC-I and PDC-TREM in pDCs activated by CpG (Fig. 4A). However, TGF- $\beta$ did not affect the basal expression of these markers. IFN- $\beta$ production was also strongly reduced in the presence of TGF- $\beta$, and a significant decrease in the production of TNF- $\alpha$, MIP1- $\alpha$, MIP1- $\beta$ and Eotaxin (Fig. 4B) was observed. 


\section{The lack of plasmacytoid dendritic cells inhibits the growth of TC-1 tumors}

To investigate whether pDCs have an impact on tumor growth, we next used $\mathrm{IK}^{\mathrm{L} / \mathrm{L}} \mathrm{Rag}^{-/-}$mice, which are constitutively deficient in pDCs but also lack T and B cells (6). This mouse strain is a powerful model to explore the influence of pDCs on anti-tumor innate immunity in vivo. The $\mathrm{IK}^{\mathrm{L} / \mathrm{L}} \mathrm{Rag}^{-/-}$mice were thus grafted with TC-1 tumor cells, and the tumor progression was followed (Fig. 5A). The tumor growth was significantly reduced in $\mathrm{IK}^{\mathrm{L} / \mathrm{L}} \mathrm{Rag}^{-/-}$mice compared with $\mathrm{IK}^{+/+} \mathrm{Rag}^{-/-}$and C57BL/6 control mice, suggesting that pDCs enhance the growth of the TC-1 tumor. However, in contrast, no difference in the growth of the B16-OVA tumor was observed between these strains of mice (Fig. 5B).

We then characterized the cytokines and chemokines present in TCM prepared from $\mathrm{IK}^{\mathrm{L} / \mathrm{L}} \mathrm{Rag}^{-/-}, \mathrm{IK}^{+/+} \mathrm{Rag}^{-/-}$and C57BL/6 control mice by the 26-plex Luminex assay or by ELISA (Supplementary Fig. S7A-D). These results clearly confirmed that MIP-2, MCP-1, MCP-3, IL-6, IL-18, Gro- $\alpha$ and TGF- $\beta$ were present in TCM from C57BL/6 and also demonstrated that similar levels of these factors were present in TCM from $\mathrm{IK}^{\mathrm{L} / \mathrm{L}} \mathrm{Rag}^{-/-}$and $\mathrm{IK}^{+/+} \mathrm{Rag}^{-/-}$mice. These results strongly suggest that these cytokines and chemokines were directly produced by the TC-1 tumor cells. In addition, the TCM prepared from $\mathrm{IK}^{\mathrm{L} / \mathrm{L}} \mathrm{Rag}^{-/-}, \mathrm{IK}^{+/+} \mathrm{Rag}^{-/-}$and C57BL/6 mice inhibited the production of IFN- $\alpha$ by pDCs activated by $\mathrm{CpG}$, as well as their maturation, with a similar efficacy.

In the absence of $\mathrm{T}$ and $\mathrm{B}$ cells, NK cells represent the main effector cells that could be involved in tumor protection in $\mathrm{IK}^{\mathrm{L} / \mathrm{L}} \mathrm{Rag}^{-/-}$mice. Intratumoral NK1.1 ${ }^{+} \mathrm{NK}$ cells were thus analyzed at different time points (Fig. 5C). Although the frequency of NK cells among hematopoietic cells clearly diminished during tumor progression, the total number of NK cells was significantly increased in all strains of mice at days 25 or 35 . Interestingly, despite a 
reduced growth of the TC-1 tumor, the number of intratumoral NK cells was significantly lower in $\mathrm{IK}^{\mathrm{L} / \mathrm{L}} \mathrm{Rag}^{-/-}$than that in $\mathrm{IK}^{+/+} \mathrm{Rag}^{-/-}$and $\mathrm{C} 57 \mathrm{BL} / 6$ mice.

To further decipher the role of NK cells in the tumor protection observed in $\mathrm{IK}^{\mathrm{L} / \mathrm{L}} \mathrm{Rag}^{-/-}$, mice were treated with an anti-NK1.1 antibody to deplete NK cells (Supplementary Fig. S8A). Following this treatment, a higher and significant increase in TC-1 growth was observed in $\mathrm{IK}^{\mathrm{L} / \mathrm{L}} \mathrm{Rag}^{-/-}$mice, whereas NK cell depletion did not affect the growth of TC-1 tumors in $\mathrm{IK}^{+/+} \mathrm{Rag}^{-/-}$and C57BL/6 control mice (Fig. 5D).

These results indicate that, despite their lower numbers, NK cells were responsible for the better control of the TC-1 tumor growth in these mice. Because NK cells were less represented in the tumors of $\mathrm{IK}^{\mathrm{L} / \mathrm{L}} \mathrm{Rag}^{-/-}$mice, compared with $\mathrm{IK}^{+/+} \mathrm{Rag}^{-/-}$, we next analyzed their maturation status, according to the expression of CD11b and CD27 (Fig. 5E). Most NK cells infiltrating the tumor in $\mathrm{IK}^{\mathrm{L} / \mathrm{L}} \mathrm{Rag}^{-/-}$were $\mathrm{CD} 11 \mathrm{~b}^{+} \mathrm{CD} 27^{-}$, corresponding to the more mature NK cells (32). By contrast, $\mathrm{CD} 11 \mathrm{~b}^{+} \mathrm{CD} 27^{+} \mathrm{NK}$ cells were highly represented in the tumors of $\mathrm{IK}^{+/+} \mathrm{Rag}^{-/-}$and C57BL/6 control mice (Fig. 5E). These differences were not observed in the spleen of tumor-bearing mice, although a higher percentage of $\mathrm{CD} 11 \mathrm{~b}^{+} \mathrm{CD} 27^{-}$ was present in C57BL/6 mice (Supplementary Fig. S8B).

These results demonstrated that, in the absence of pDCs, a higher percentage of mature $\mathrm{CD} 11 \mathrm{~b}^{+} \mathrm{CD} 27^{-} \mathrm{NK}$ cells could be observed in the tumors of $\mathrm{IK}^{\mathrm{L} / \mathrm{L}} \mathrm{Rag}^{-/-}$, which can control tumor growth.

To further elucidate the role of TGF- $\beta$ in the growth of tumors, wild-type C57BL/6, IK ${ }^{\mathrm{L} / \mathrm{L}}$ $\mathrm{Rag}^{-/-}$and $\mathrm{IK}^{+/+} \mathrm{Rag}^{-/-}$mice were treated either by the anti-TGF- $\beta$ antibody $1 \mathrm{D} 11.16 .8$ or by control isotype. This antibody had been demonstrated to potently inhibit TGF- $\beta$ in several infectious or tumor models $(30,31)$. The results of this experiment clearly evidenced that TGF- $\beta$ blockade strongly reduced the TC-1 growth in C57BL/6 mice (Figure 6A and Supplementary Fig. S9A-C). However, this treatment did not affect the tumor growth in 
either $\mathrm{IK}^{\mathrm{L} / \mathrm{L}} \mathrm{Rag}^{-/-}$or $\mathrm{IK}^{+/+}$Rag-/- mice, demonstrating that the inhibition of anti-tumor responses by TGF- $\beta$ is mediated through the suppression of adaptive immune responses.

Thus, to decipher the role of adaptive immune responses in the cross-talk between tumor cells and $\mathrm{pDCs}, \mathrm{IK}^{\mathrm{L} / \mathrm{L}} \mathrm{Rag}^{-/-}$and $\mathrm{IK}^{+/+} \mathrm{Rag}^{-/-}$mice were reconstituted with pDC-depleted splenocytes from Foxp3-GFP mice, followed by the graft of TC-1 cells. As previously observed with non-reconstituted $\mathrm{IK}^{\mathrm{L} / \mathrm{L}} \mathrm{Rag}^{-/-}$(Fig. 5A), the growth of the TC-1 tumor was significantly reduced in reconstituted $\mathrm{IK}^{\mathrm{L} / \mathrm{L}} \mathrm{Rag}^{-/-} \mathrm{pDC}$ - deficient mice, compared with $\mathrm{IK}^{+/+}$ $\mathrm{Rag}^{-/-}$and C57BL/6 mice (Fig. 6B). In addition, a decreased recruitment of CD4 ${ }^{+} \mathrm{FoxP}^{+}$ cells was observed in the reconstituted $\mathrm{IK}^{\mathrm{L} / \mathrm{L}} \mathrm{Rag}^{-/-}$mice, compared with $\mathrm{IK}^{+/+} \mathrm{Rag}^{-/-}$mice (Fig. 6C-D).

These results strongly suggest that, in the presence of adaptive immune responses, pDCs promote tumor growth through the increased recruitment of $\mathrm{CD} 4^{+} \mathrm{FoxP} 3^{+}$Treg cells. 


\section{DISCUSSION}

A growing number of observations has suggested that pDCs play a critical role in tumor biology. In the present study, we use two different mouse tumor models to show that pDCs are recruited into the tumor microenvironment. Phenotypical and gene expression analysis showed that these TA-pDCs are activated but that the tumoral microenvironment strongly affects the innate response of TA-pDCs to TLR-9 signaling. In addition, we demonstrate that the production of TGF- $\beta$ by tumor cells is responsible for the observed inhibition. Furthermore, using a mouse model deficient in pDCs, we show that the absence of pDCs promotes protective anti-tumor responses, mediated by the recruitment of differentiated NK cells and associated with a decreased infiltration of Tregs.

Our demonstration that pDCs accumulated during tumor growth is in agreement with previous observations in human cancers, such as cervical carcinoma (33) and melanoma (22,33-35). The phenotype and gene expression profile of pDCs infiltrating the TC-1 and B16-OVA tumors were clearly distinct from the pDCs from the spleens of naïve or tumor-bearing mice. TA-pDCs were activated at the early stages of tumor development but exhibited at later stages a complex transcriptomic profile characterized by the downregulation of genes belonging to the DC maturation pathway. Importantly, this downregulation was associated with the upregulation of genes involved in Ag processing. Thus, this potential increase in the capacity of TA-pDCs to process Ag, associated with a defect in their maturation, could provide a tolerogenic potential of these cells.

In both tumor models, we observed the upregulation of the genes associated with the activation of interferon regulatory factors (IRF) by the cytosolic pattern recognition receptor (PRR) pathway, supporting our conclusion that pDCs infiltrating the tumor are activated. Although the phenotype of pDCs in the spleen of tumor-bearing mice was not significantly different from naïve splenic pDCs, their expression of genes associated with activation was 
however upregulated, suggesting that splenic pDCs are affected by factors released by the tumor.

Activation of IRF by cytosolic PRR generally leads to the production of IFN-I by pDCs, which is tightly correlated with the expression of PDC-TREM by pDCs through the regulation of signals such as DAP-12, PI3K and Erk (36). Both TC-1 and B16-OVA TA-pDC upregulated PDC-TREM at the early stages of tumor development. However, its expression decreased during tumor growth, suggesting that TA-pDCs produce IFN-I at early stage of tumor growth, but progressively lost this ability in the tumor context. According to this observation, we showed that the factors produced by both the TC-1 and B16-OVA tumors strongly inhibited the production of IFN-I by pDCs stimulated by $\mathrm{CpG}$. These results are in agreement with the demonstration that human naïve pDCs, cultured in the presence of supernatants derived from head and neck $(21,37,38)$, ovarian (18) and breast $(24,39)$ cancers, exhibited a diminished ability to produce IFN- $\alpha$ following TLR-9 stimulation.

We clearly identified TGF- $\beta$ as the main factor capable of blocking IFN-I production by TApDCs. TGF- $\beta$ is present in the TC-1 and B16-OVA TCM from C57BL/6 and $\mathrm{Rag}^{-/-}$mice, as well as in the TC-1 and B16-OVA SUP, demonstrating that TGF- $\beta$ is produced by tumor cells in the absence of $\mathrm{T}$ cells. This conclusion is in agreement with previous studies demonstrating that following TGF- $\beta$ exposure, pDCs have a decrease capacity to produce IFN- $\alpha$ in response to TLR-9 ligand $(18,37,39,40)$, in both humans $(37)$ and mice $(40,41)$. While TGF- $\beta$ alone could strongly inhibit the production of IFN-Is, we observed only a partial effect of this cytokine on the maturation of $\mathrm{pDCs}$ and their capacity to produce other cytokines, suggesting that other factor(s) produced by the tumor cells could be involved in this inhibition. TNF- $\alpha$ has been shown to act in synergy with TGF- $\beta$ to inhibit the production of IFN- $\alpha$ by pDCs infiltrating ovarian human cancer $(18,39)$. However, we did not detect TNF- $\alpha$ in the TC-1 tumor supernatants, ruling out such a synergistic effect. Similarly, in Peyer's patches, PGE-2 
has been shown to synergize with TGF- $\beta$ to prevent IFN- $\alpha$ production by pDCs following TLR stimulation (40). A similar synergy was also observed in the tumor context (37). It remains to be determined whether PGE-2 is produced by TC-1 and B16-OVA tumor cells, which could explain why high doses of TGF- $\beta$ significantly impaired, but did not fully abrogate, the capacity of pDCs to produce IFN- $\alpha$, in contrast to the TC- 1 supernatant.

In humans, the accumulation of pDCs in tumors generally correlates with a poor clinical outcome. In mice, the depletion of pDCs by an anti-CD317 Ab was shown to delay the tumor growth through the regulation of T-cell responses $(23,42)$. Here, using the pDC-deficient $\mathrm{IK}^{\mathrm{L} / \mathrm{L}} \mathrm{Rag}^{-/-}$mice (6), we show that the growth of TC-1 tumors is significantly reduced in the absence of pDCs, compared with $\mathrm{IK}^{+/+} \mathrm{Rag}^{-/-}$and C57BL/6 control mice. In addition, NK depletion induced a higher and significant increase in the TC-1 growth in $\mathrm{IK}^{\mathrm{L} / \mathrm{L}} \mathrm{Rag}^{-/-}$mice, but did not affect the growth of TC-1 tumors in $\mathrm{IK}^{+/+} \mathrm{Rag}^{-/-}$and $\mathrm{C} 57 \mathrm{BL} / 6$ control mice. These results clearly indicate that NK cells were responsible for the better control of the TC-1 tumor growth in $\mathrm{IK}^{\mathrm{L} / \mathrm{L}} \mathrm{Rag}^{-/-}$mice. Since the only difference between $\mathrm{IK}^{\mathrm{L} / \mathrm{L}} \mathrm{Rag}^{-/-}$or $\mathrm{IK}^{+/+} \mathrm{Rag}^{-/-}$mice is the lack of pDCs, it thus could be concluded that the absence of pDCs leads to the activation of NK cells, by mechanisms which remain to be deciphered. Indeed, we observed an increased representation of the $\mathrm{CD} 11 \mathrm{~b}^{+} \mathrm{CD} 27^{\text {low }} \mathrm{NK}$ cell subset in $\mathrm{IK}^{\mathrm{L} / \mathrm{L}} \mathrm{Rag}^{-/-}$mice, whereas the $\mathrm{CD} 11 \mathrm{~b}^{+} \mathrm{CD} 27^{+} \mathrm{NK}$ cell subset was predominant in $\mathrm{IK}^{+/+} \mathrm{Rag}^{-/-}$or $\mathrm{C} 57 \mathrm{BL} / 6$ mice. The $\mathrm{CD} 11 \mathrm{~b}^{+} \mathrm{CD} 27^{\text {low }} \mathrm{NK}$ cells represent the final maturation stage of NK cells and exhibit high cytolytic function in both humans (43) and mice (32). By contrast, the CD11b $\mathrm{b}^{+} \mathrm{CD} 27^{+}$ NK cells have the strongest ability to secrete cytokines (43). Interestingly, the $\mathrm{CD} 11 \mathrm{~b}^{+} \mathrm{CD} 27^{\text {low }} \mathrm{NK}$ cell subset is less represented in naïve $\mathrm{IK}^{\mathrm{L} / \mathrm{L}} \mathrm{Rag}^{-/-}$mice (6).

In contrast to the TC-1 tumor, the growth of the B16-OVA tumor was not modified by the absence of pDCs. This discrepancy between these two tumors could be linked to the lack of expression of NKG2D ligands by B16 tumors (44), leading to an inefficient killing by NK 
cells. This hypothesis is in full agreement with the demonstration that NK cells play a major role in the protection observed in $\mathrm{IK}^{\mathrm{L} / \mathrm{L}} \mathrm{Rag}^{-/-}$mice grafted with TC-1 cells.

It is well established that pDCs enhanced NK cell functions, especially cytotoxicity (45) through the production of IFN-I (46). However, our present study suggests that pDCs could also negatively regulate NK activity in a tumor context, since the lack of pDCs leads to an increased infiltration/maturation of potentially highly cytotoxic NK cells, allowing a better control of the tumor growth.

The growth of TC-1 tumor was significantly delayed in pDC-deficient mice reconstituted with pDC-depleted splenocytes, in association with a strong reduction of intratumoral Treg recruitment, compared to $\mathrm{C} 57 \mathrm{BL} / 6$ and $\mathrm{IK}^{+/+} \mathrm{Rag}^{-/-}$control mice. This observation is in full agreement with human studies showing that TA-pDCs promote the expansion of Treg cells, through their inability to produce IFN-I (24). TGF- $\beta$ and TNF- $\alpha$ were clearly identified as the major tumoral factors involved in this process (39). These results suggest that TGF- $\beta$ inhibits the production of IFN-I by TA-pDCs, thus leading to an increase recruitment/proliferation of intratumoral Treg, as suggested in breast cancer patients (47). In immunocompetent C57BL/6 mice, TGF- $\beta$ blockade strongly reduced the TC-1 growth in C57BL/6 mice. However, this treatment did not affect the tumor growth in either $\mathrm{IK}^{\mathrm{L} / \mathrm{L}} \mathrm{Rag}^{-/-}$or $\mathrm{IK}^{+/+} \mathrm{Rag}^{-/-}$mice. In C57BL/6 mice, we have previously demonstrated a massive accumulation of Tregs at the tumor site very early after tumor inoculation, which represented up to $80 \%$ of tumor-infiltrating CD4 ${ }^{+} \mathrm{T}$ cells $(48,49)$. In addition, we have also shown that the growth of the TC-1 tumor is delayed in C57BL/6 mice treated by anti-CD25 to deplete Treg cells (49). Finally, this study also demonstrated that, in contrast to $\mathrm{IK}^{\mathrm{L} / \mathrm{L}} \mathrm{Rag}^{-/-}$, NK cell depletion did not affect the growth of TC-1 tumors in C57BL/6 control mice. Thus, it could be suggested that in C57BL/6 mice, TGF- $\beta$ promote the recruitment of Treg cells, which in turn inhibit adaptive anti-tumoral responses. 
Thus, in conclusion, this study demonstrates that different mechanisms, involving pDCs and/or TGF- $\beta$, can damper anti-tumor immune responses. First, pDCs interact with the development of anti-tumor innate response through the alteration of the recruitment of mature NK cells, by a TGF- $\beta$-independent mechanism. In addition, TGF- $\beta$ down regulates pDC innate responses, but also affects adaptive immune response through the recruitment of Treg in the tumor. Altogether, these results demonstrate that pDCs represent an important target for the development of new immunotherapies for the treatment of cancer. 


\section{REFERENCES}

1. Asselin-Paturel C, Boonstra A, Dalod M, Durand I, Yessaad N, Dezutter-Dambuyant

C, et al. Mouse type I IFN-producing cells are immature APCs with plasmacytoid morphology. Nat Immunol 2001;2(12):1144-50.

2. O'Keeffe M, Hochrein H, Vremec D, Caminschi I, Miller JL, Anders EM, et al. Mouse plasmacytoid cells: long-lived cells, heterogeneous in surface phenotype and function, that differentiate into $\mathrm{CD} 8(+)$ dendritic cells only after microbial stimulus. J Exp Med 2002;196(10):1307-19.

3. Asselin-Paturel C, Brizard G, Pin JJ, Briere F, Trinchieri G. Mouse strain differences in plasmacytoid dendritic cell frequency and function revealed by a novel monoclonal antibody. J Immunol 2003;171(12):6466-77.

4. Yang GX, Lian ZX, Kikuchi K, Liu YJ, Ansari AA, Ikehara S, et al. CD4plasmacytoid dendritic cells (pDCs) migrate in lymph nodes by $\mathrm{CpG}$ inoculation and represent a potent functional subset of pDCs. J Immunol 2005;174(6):3197-203.

5. Iparraguirre A, Tobias JW, Hensley SE, Masek KS, Cavanagh LL, Rendl M, et al. Two distinct activation states of plasmacytoid dendritic cells induced by influenza virus and CpG 1826 oligonucleotide. J Leukoc Biol 2008;83(3):610-20.

6. Guillerey C, Mouries J, Polo G, Doyen N, Law HK, Chan S, et al. Pivotal role of plasmacytoid dendritic cells in inflammation and NK-cell responses after TLR9 triggering in mice. Blood 2012;120(1):90-9.

7. Marschner A, Rothenfusser S, Hornung V, Prell D, Krug A, Kerkmann M, et al. CpG ODN enhance antigen-specific NKT cell activation via plasmacytoid dendritic cells. Eur J Immunol 2005;35(8):2347-57. 
8. Montoya CJ, Jie HB, Al-Harthi L, Mulder C, Patino PJ, Rugeles MT, et al. Activation of plasmacytoid dendritic cells with TLR9 agonists initiates invariant NKT cell-mediated cross-talk with myeloid dendritic cells. J Immunol 2006;177(2):1028-39.

9. Gilliet M, Cao W, Liu YJ. Plasmacytoid dendritic cells: sensing nucleic acids in viral infection and autoimmune diseases. Nat Rev Immunol 2008;8(8):594-606.

10. Villadangos JA, Young L. Antigen-presentation properties of plasmacytoid dendritic cells. Immunity 2008;29(3):352-61.

11. Mouries J, Moron G, Schlecht G, Escriou N, Dadaglio G, Leclerc C. Plasmacytoid dendritic cells efficiently cross-prime naive $\mathrm{T}$ cells in vivo after TLR activation. Blood 2008;112(9):3713-22.

12. Schlecht G, Garcia S, Escriou N, Freitas AA, Leclerc C, Dadaglio G. Murine plasmacytoid dendritic cells induce effector/memory CD8+ T-cell responses in vivo after viral stimulation. Blood 2004;104(6):1808-15.

13. Matta BM, Castellaneta A, Thomson AW. Tolerogenic plasmacytoid DC. Eur J Immunol 2010;40(10):2667-76.

14. de Heer HJ, Hammad H, Soullie T, Hijdra D, Vos N, Willart MA, et al. Essential role of lung plasmacytoid dendritic cells in preventing asthmatic reactions to harmless inhaled antigen. J Exp Med 2004;200(1):89-98.

15. Goubier A, Dubois B, Gheit H, Joubert G, Villard-Truc F, Asselin-Paturel C, et al. Plasmacytoid dendritic cells mediate oral tolerance. Immunity 2008;29(3):464-75.

16. Fugier-Vivier IJ, Rezzoug F, Huang Y, Graul-Layman AJ, Schanie CL, Xu H, et al. Plasmacytoid precursor dendritic cells facilitate allogeneic hematopoietic stem cell engraftment. J Exp Med 2005;201(3):373-83. 
17. Wei S, Kryczek I, Zou L, Daniel B, Cheng P, Mottram P, et al. Plasmacytoid dendritic cells induce $\mathrm{CD} 8+$ regulatory $\mathrm{T}$ cells in human ovarian carcinoma. Cancer Res 2005;65(12):5020-6.

18. Labidi-Galy SI, Sisirak V, Meeus P, Gobert M, Treilleux I, Bajard A, et al. Quantitative and functional alterations of plasmacytoid dendritic cells contribute to immune tolerance in ovarian cancer. Cancer Res 2011;71(16):5423-34.

19. Conrad C, Gregorio J, Wang YH, Ito T, Meller S, Hanabuchi S, et al. Plasmacytoid dendritic cells promote immunosuppression in ovarian cancer via ICOS costimulation of Foxp3(+) T-regulatory cells. Cancer Res 2012;72(20):5240-9.

20. Faget J, Bendriss-Vermare N, Gobert M, Durand I, Olive D, Biota C, et al. ICOSligand expression on plasmacytoid dendritic cells supports breast cancer progression by promoting the accumulation of immunosuppressive CD4+ $\mathrm{T}$ cells. Cancer Res 2012;72(23):6130-41.

21. Hartmann E, Wollenberg B, Rothenfusser S, Wagner M, Wellisch D, Mack B, et al. Identification and functional analysis of tumor-infiltrating plasmacytoid dendritic cells in head and neck cancer. Cancer Res 2003;63(19):6478-87.

22. Salio M, Cella M, Vermi W, Facchetti F, Palmowski MJ, Smith CL, et al. Plasmacytoid dendritic cells prime IFN-gamma-secreting melanoma-specific CD8 lymphocytes and are found in primary melanoma lesions. Eur J Immunol 2003;33(4):105262.

23. Le Mercier I, Poujol D, Sanlaville A, Sisirak V, Gobert M, Durand I, et al. Tumor promotion by intratumoral plasmacytoid dendritic cells is reversed by TLR7 ligand treatment. Cancer Res 2013;73(15):4629-40. 
24. Sisirak V, Faget J, Gobert M, Goutagny N, Vey N, Treilleux I, et al. Impaired IFNalpha production by plasmacytoid dendritic cells favors regulatory T-cell expansion that may contribute to breast cancer progression. Cancer Res 2012;72(20):5188-97.

25. Faget J, Sisirak V, Blay JY, Caux C, Bendriss-Vermare N, Menetrier-Caux C. ICOS is associated with poor prognosis in breast cancer as it promotes the amplification of immunosuppressive CD4+ $\mathrm{T}$ cells by plasmacytoid dendritic cells. Oncoimmunology 2013;2(3):e23185.

26. Tel J, Aarntzen EH, Baba T, Schreibelt G, Schulte BM, Benitez-Ribas D, et al. Natural human plasmacytoid dendritic cells induce antigen-specific T-cell responses in melanoma patients. Cancer Res 2013;73(3):1063-75.

27. Liu C, Lou Y, Lizee G, Qin H, Liu S, Rabinovich B, et al. Plasmacytoid dendritic cells induce NK cell-dependent, tumor antigen-specific $\mathrm{T}$ cell cross-priming and tumor regression in mice. J Clin Invest 2008;118(3):1165-75.

28. Shinkai Y, Rathbun G, Lam KP, Oltz EM, Stewart V, Mendelsohn M, et al. RAG-2deficient mice lack mature lymphocytes owing to inability to initiate V(D)J rearrangement. Cell 1992;68(5):855-67.

29. Wang Y, Kissenpfennig A, Mingueneau M, Richelme S, Perrin P, Chevrier S, et al. Th2 lymphoproliferative disorder of LatY136F mutant mice unfolds independently of TCRMHC engagement and is insensitive to the action of Foxp3+ regulatory $\mathrm{T}$ cells. $\mathrm{J}$ Immunol 2008;180(3):1565-75.

30. Garidou L, Heydari S, Gossa S, McGavern DB. Therapeutic blockade of transforming growth factor beta fails to promote clearance of a persistent viral infection. J Virol 2012;86(13):7060-71. 
31. Greco SH, Tomkotter L, Vahle AK, Rokosh R, Avanzi A, Mahmood SK, et al. TGFbeta Blockade Reduces Mortality and Metabolic Changes in a Validated Murine Model of Pancreatic Cancer Cachexia. PLoS One 2015;10(7):e0132786.

32. Chiossone L, Chaix J, Fuseri N, Roth C, Vivier E, Walzer T. Maturation of mouse NK cells is a 4-stage developmental program. Blood 2009;113(22):5488-96.

33. Bontkes HJ, Ruizendaal JJ, Kramer D, Meijer CJ, Hooijberg E. Plasmacytoid dendritic cells are present in cervical carcinoma and become activated by human papillomavirus type 16 virus-like particles. Gynecol Oncol 2005;96(3):897-901.

34. Charles J, Di Domizio J, Salameire D, Bendriss-Vermare N, Aspord C, Muhammad R, et al. Characterization of circulating dendritic cells in melanoma: role of CCR6 in plasmacytoid dendritic cell recruitment to the tumor. J Invest Dermatol 2010;130(6):1646-56.

35. Vermi W, Bonecchi R, Facchetti F, Bianchi D, Sozzani S, Festa S, et al. Recruitment of immature plasmacytoid dendritic cells (plasmacytoid monocytes) and myeloid dendritic cells in primary cutaneous melanomas. J Pathol 2003;200(2):255-68.

36. Watarai H, Sekine E, Inoue S, Nakagawa R, Kaisho T, Taniguchi M. PDC-TREM, a plasmacytoid dendritic cell-specific receptor, is responsible for augmented production of type I interferon. Proc Natl Acad Sci U S A 2008;105(8):2993-8.

37. Bekeredjian-Ding I, Schafer M, Hartmann E, Pries R, Parcina M, Schneider P, et al. Tumour-derived prostaglandin E and transforming growth factor-beta synergize to inhibit plasmacytoid dendritic cell-derived interferon-alpha. Immunology 2009;128(3):439-50.

38. Thiel A, Pries R, Jeske S, Trenkle T, Wollenberg B. Effect of head and neck cancer supernatant and CpG-oligonucleotides on migration and IFN-alpha production of plasmacytoid dendritic cells. Anticancer Res 2009;29(8):3019-25.

39. Sisirak V, Vey N, Goutagny N, Renaudineau S, Malfroy M, Thys S, et al. Breast cancer-derived transforming growth factor-beta and tumor necrosis factor-alpha compromise 
interferon-alpha production by tumor-associated plasmacytoid dendritic cells. Int $\mathrm{J}$ Cancer 2013;133(3):771-8.

40. Contractor N, Louten J, Kim L, Biron CA, Kelsall BL. Cutting edge: Peyer's patch plasmacytoid dendritic cells (pDCs) produce low levels of type I interferons: possible role for IL-10, TGFbeta, and prostaglandin E2 in conditioning a unique mucosal pDC phenotype. J Immunol 2007;179(5):2690-4.

41. Li L, Liu S, Zhang T, Pan W, Yang X, Cao X. Splenic stromal microenvironment negatively regulates virus-activated plasmacytoid dendritic cells through TGF-beta. J Immunol 2008;180(5):2951-6.

42. Sawant A, Hensel JA, Chanda D, Harris BA, Siegal GP, Maheshwari A, et al. Depletion of plasmacytoid dendritic cells inhibits tumor growth and prevents bone metastasis of breast cancer cells. J Immunol 2012;189(9):4258-65.

43. Fu B, Wang F, Sun R, Ling B, Tian Z, Wei H. CD11b and CD27 reflect distinct population and functional specialization in human natural killer cells. Immunology 2011;133(3):350-9.

44. Diefenbach A, Jamieson AM, Liu SD, Shastri N, Raulet DH. Ligands for the murine NKG2D receptor: expression by tumor cells and activation of NK cells and macrophages. Nat Immunol 2000;1(2):119-26.

45. Romagnani C, Della Chiesa M, Kohler S, Moewes B, Radbruch A, Moretta L, et al. Activation of human NK cells by plasmacytoid dendritic cells and its modulation by CD4+ T helper cells and CD4+ CD25hi T regulatory cells. Eur J Immunol 2005;35(8):2452-8.

46. Gerosa F, Gobbi A, Zorzi P, Burg S, Briere F, Carra G, et al. The reciprocal interaction of NK cells with plasmacytoid or myeloid dendritic cells profoundly affects innate resistance functions. J Immunol 2005;174(2):727-34. 
47. Sisirak V, Faget J, Vey N, Blay JY, Menetrier-Caux C, Caux C, et al. Plasmacytoid dendritic cells deficient in IFNalpha production promote the amplification of FOXP3(+) regulatory $\mathrm{T}$ cells and are associated with poor prognosis in breast cancer patients. Oncoimmunology 2013;2(1):e22338.

48. Sainz-Perez A, Lim A, Lemercier B, Leclerc C. The T-cell receptor repertoire of tumor-infiltrating regulatory $\mathrm{T}$ lymphocytes is skewed toward public sequences. Cancer Res 2012;72(14):3557-69.

49. Chaoul N, Tang A, Desrues B, Oberkampf M, Fayolle C, Ladant D, et al. Lack of MHC class II molecules favors CD8(+) T-cell infiltration into tumors associated with an increased control of tumor growth. Oncoimmunology 2018;7(3):e1404213. 


\section{FIGURE LEGENDS}

\section{Figure 1. pDCs infiltrate TC-1 and B16-OVA tumors and show an activated profile}

C57BL/6 mice were grafted with $5 \times 10^{5}$ TC- 1 cells (red curves and symbols) or $2.5 \times 10^{5} \mathrm{~B} 16-$ OVA cells (blue curves and symbols) at day 0 , and the tumor growth was followed until day 30 for the TC-1 tumor and day 25 for the B16-OVA tumor. The presence of pDCs in the TC-1 and B16-OVA tumors, as well as their phenotype, was analyzed by FACS at different time points. (A) Growth of TC-1 and B16-OVA tumors, respectively. Each curve represents the tumor diameter of an individual mouse. The graph shows the cumulative results of 56 mice for TC-1 tumors and 48 mice for B16-OVA from three independent experiments. (B) Total number of live cells of the TC-1 and B16-OVA tumors, as defined by trypan blue staining. The results are expressed as the cumulative numbers ( 9 and 6 mice per time point for TC-1 and B16-OVA tumors, respectively) from three independent experiments for TC-1, and two independent experiments for B16-OVA. (C) Frequency and (D) number of $\mathrm{CD} 317^{+} \mathrm{CD} 11 \mathrm{c}^{\text {low }} \mathrm{B} 220^{+} \mathrm{CD} 11 \mathrm{~b}^{-} \mathrm{pDCs}$ among total $\mathrm{CD} 45^{+}$hematopoietic cells infiltrating the TC-1 and B16-OVA tumors. Numbers correspond to the number of CD45 ${ }^{+}$multiplied by the $\%$ of the cell subsets taken within the $\mathrm{CD} 45^{+}$cells. The mice were analyzed individually. The graphs show the cumulative results ( 9 and 6 mice per time point for TC-1 and B16-OVA tumors, respectively) from three independent experiments for TC-1, and two independent experiments for B16-OVA. (E-F) Expression of the activation markers and co-stimulatory molecules by pDCs infiltrating the TC-1 tumor (E, red bars) or B16-OVA tumor (F, blue bars), compared with pDCs infiltrating the naïve spleen (black bars). The data are expressed as means \pm SEM of MFI and represent the cumulative results of three independent experiments for TC-1, and two independent experiments for B16-OVA ( 9 and 6 mice per time 
point for TC-1 and B16-OVA tumors, respectively). Statistical analysis was performed using unpaired Student's $t$ test $\left({ }^{*} \mathrm{p}<0.05 ; * * \mathrm{p}<0.005 ; * * * \mathrm{p}<0.001 ; * * * * \mathrm{p}<0.0001\right)$.

Figure 2. Factors present in TC-1 TCM or secreted by TC-1 and B16-OVA tumor cells affect the phenotype of pDCs and their ability to secrete cytokines and chemokines following activation

(A and B) $10^{4} \mathrm{pDCs}$ were purified from the spleen of naïve C57BL/6 mice and were cultured in medium, TC-1 TCM (derived from TC-1 tumors harvested at day 30 after graft) or TC-1 or B16-OVA supernatants (SUP), in the presence or the absence of CpG-A. (A) The production of IFN- $\alpha$ was assessed by ELISA after 24 hours of culture with undiluted TC-1 TCM or TC-1 and B16-OVA SUP. The results are expressed as the means \pm SEM of the concentration $(\mathrm{ng} / \mathrm{mL})$ and represent the cumulative data of 3 independent experiments for each culture condition. (B) The production of IFN- $\beta$, TNF- $\alpha$, MIP1- $\alpha$, MIP1- $\beta$ and Eotaxin was assessed by the Luminex assay after 24 hours of culture with undiluted TC-1 TCM or TC-1 and B16OVA SUP. The results are expressed as the means \pm SEM of the concentration $(\mathrm{pg} / \mathrm{mL})$ and represent the cumulative data of 3 independent experiments for each culture condition. (C) pDCs were purified from the spleen of naïve C57BL/6 mice and were cultured in medium, TC-1 TCM or TC-1 or B16-OVA supernatants diluted $1 / 2$ in complete medium, in the presence or absence of $\mathrm{CpG}-\mathrm{A}$ for 18 hours. The phenotype and expression of activation markers and co-stimulatory molecules of pDCs were analyzed by FACS. The results are expressed as the means \pm SEM of MFI and represent the cumulative data of three independent experiments for each culture condition. Statistical analysis was performed by unpaired Student's t test $\left(* \mathrm{p}<0.05 ;{ }^{*} \mathrm{p}<0.005 ; * * * \mathrm{p}<0.001 ; * * * * \mathrm{p}<0.0001\right)$. DL= Detection limit. 
Figure 3. TGF- $\beta$ secreted by TC-1 or B16-OVA tumor cells suppresses the production of IFN- $\alpha$ by pDCs after CpG-A stimulation

The presence of cytokines and chemokines in the TC-1 TCM, TC-1 and B16-OVA supernatants was analyzed by (A) immunoassays using 26-plex Luminex kit or (B) by ELISA for TGF- $\beta$. The results are expressed as the means \pm SEM of the concentration $(\mathrm{ng} / \mathrm{mL}$ and $\mathrm{pg} / \mathrm{mL}$, respectively) and represent the cumulative data of 6-9 samples per condition, analyzed in triplicate. (C) The IFN- $\alpha$ production by $10^{4} \mathrm{pDCs}$ purified from the spleen of naïve C57BL/6 cultured in the presence of either undiluted TC-1-SUP or a mixture of 1 or 10 ng/mL of recombinant IL-6, IP-10, MCP-1, MCP-3, RANTES and TGF- $\beta$ and stimulated with CpG-A was assessed by ELISA. TC-1-SUP is used as the positive control. The results are expressed as the means \pm SEM of the concentration $(\mathrm{ng} / \mathrm{mL})$ and represent the cumulative data of 6-9 samples per condition, analyzed in duplicate. (D) The production of IFN- $\alpha$ by pDCs purified from the naïve spleen and cultured for 24 hours with undiluted TC-1-SUP or with serial dilutions of the recombinant cytokines or chemokines alone, in the presence of CpG-A, was assessed by ELISA. The results are expressed as the means \pm SEM of the concentration $(\mathrm{ng} / \mathrm{mL})$ and represent the cumulative data of 3 independent experiments for each culture condition. (E) The production of IFN- $\alpha$ by pDCs purified from the naïve spleen and cultured for 24 hours with undiluted TC-1-SUP or serial dilutions of recombinant TGF- $\beta$, in the presence of CpG-A, was assessed by ELISA. The results are expressed as the means \pm SEM of the concentration $(\mathrm{ng} / \mathrm{mL})$ and represent the cumulative data of 3 independent experiments for each culture condition. (F) IFN- $\alpha$ production by purified pDCs from the spleen of naïve C57BL/6 cultured in the presence of TC-1-SUP or $10 \mathrm{ng} / \mathrm{mL}$ of recombinant IL-6, IP-10, MCP-1, MCP-3 and RANTES and various concentrations of TGF- $\beta$ (0 to 10 $\mathrm{ng} / \mathrm{ml}$ ) and stimulated with CpG-A was assessed by ELISA. The results are expressed as the means \pm SEM of concentration $(\mathrm{ng} / \mathrm{mL})$ and represent the cumulative data of 6-9 samples per 
condition, analyzed in duplicate. Statistical analysis was performed by unpaired Student's t test $(* \mathrm{p}<0.05 ; * * \mathrm{p}<0.005 ; * * * \mathrm{p}<0.001 ; * * * * \mathrm{p}<0.0001) . \mathrm{DL}=$ Detection limit.

\section{Figure 4. TGF- $\beta$ alters the phenotype and functions of pDCs activated by CpG-A}

$10^{4}$ pDCs were purified from the spleen of naïve C57BL/6 and were cultured in the presence of 1 or $10 \mathrm{ng} / \mathrm{mL}$ of TGF- $\beta$ with or without CpG-A. (A) The expression of activation markers and co-stimulatory molecules by pDCs was assessed after 6 hours of culture. The results are expressed as the means \pm SEM of the MFI. The data represent the cumulative results of three independent experiments. (B) The production of cytokines and chemokines by pDCs was assessed by the Luminex assay after 18 hours of culture. The results are expressed as the means \pm SEM of the concentration $(\mathrm{pg} / \mathrm{mL})$. The data represent the cumulative results of three independent experiments. Statistical analysis was performed by unpaired Student's t test $(* \mathrm{p}<0.05 ; * * \mathrm{p}<0.005 ; * * * \mathrm{p}<0.001 ; * * * * \mathrm{p}<0.0001) . \mathrm{DL}=$ Detection limit.

\section{Figure 5. pDCs exert a deleterious effect on the growth of the TC-1 tumor}

$\mathrm{C} 57 \mathrm{BL} / 6, \mathrm{IK}^{\mathrm{L} / \mathrm{L}} \mathrm{Rag}^{-/-}$and $\mathrm{IK}^{+/+} \mathrm{Rag}^{-/-}$mice were grafted with $5 \times 10^{5} \mathrm{TC}-1$ or $2.5 \times 10^{5} \mathrm{~B} 16-$ OVA cells at day 0 , and the tumor growth was followed. Growth of the TC-1 (A) and B16OVA (B) tumors. The curves represent the means \pm SEM of the tumor diameter for each group and show the cumulative results from three $(\mathrm{A}, \mathrm{n}=8$ to 12 mice per strain per experiment) or two (B, $\mathrm{n}=10$ mice per strain per experiment) independent experiments. (C) Frequency among the total $\mathrm{CD} 45^{+}$hematopoietic cells and total number of CD3-NK1.1 ${ }^{+} \mathrm{NK}$ cells infiltrating the TC- 1 tumor. Numbers correspond to the number of CD $45^{+}$multiplied by the $\%$ of the cell subsets taken within the $\mathrm{CD} 45^{+}$cells. The mice were analyzed individually. The graphs show the cumulative results of three independent experiments ( $n=3$ to 5 mice per strain per experimental time point). (D) C57BL/6, $\mathrm{IK}^{\mathrm{L} / \mathrm{L}} \mathrm{Rag}^{-/-}$and $\mathrm{IK}^{+/+} \mathrm{Rag}^{-/-}$mice were 
grafted with $5 \times 10^{5}$ TC-1 cells at day 0 and were treated with i.p. injections of anti-NK1.1 antibodies or control isotype on day -1 and then once a week for five weeks. Each curve represents the tumor diameter of an individual mouse. The results are expressed as the cumulative data of two independent experiments $(n=10$ mice per strain per experiment). (E) Left panel: FACS dot blot showing the NK cell subsets according to the expression of CD11b and CD27 markers in the TC-1 tumors in C57BL/6, $\mathrm{IK}^{\mathrm{L} / \mathrm{L}} \mathrm{Rag}^{-/-}$and $\mathrm{IK}^{+/+} \mathrm{Rag}^{-/-} \mathrm{TC}-1$ mice 35

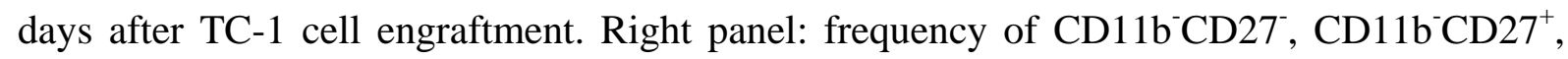

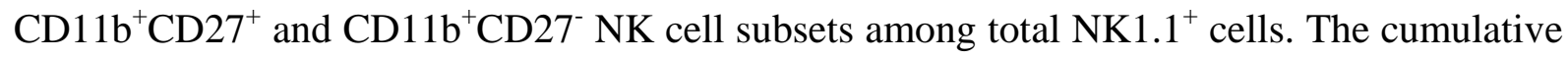
results of two independent experiments are shown as the means \pm SEM ( $n=3$ to 5 mice per strain per experiment). Statistical analysis was performed by unpaired Student's t test $\left({ }^{*} \mathrm{p}<0.05 ; * * \mathrm{p}<0.005\right)$.

Figure 6. pDCs promote tumor growth through the increased recruitment of $\mathrm{CD4}^{+}$ FoxP3 ${ }^{+}$Treg cells. (A) C57BL/6, $\mathrm{IK}^{\mathrm{L} / \mathrm{L}} \mathrm{Rag}^{-/-}$and $\mathrm{IK}^{+/+} \mathrm{Rag}^{-/-}$mice were grafted with $5 \times 10^{5}$ TC-1 cells at day 0 and were treated with i.p. injections of $500 \mu \mathrm{g}$ anti-TGF- $\beta$ antibodies (clone 1D11.16.8) or control isotype on day -1 and then three times a week for five weeks. The tumor growth was followed until day 35 . The curves represent the means \pm SEM of the tumor diameter for each group. The results represent the cumulative data from 2 independent experiments ( $\mathrm{n}=12$ to 14 mice per group). Statistical analysis was performed by Wilcoxon test (ns: non-significant; *** $\mathrm{p}<0.001$ ). (B-D) $\mathrm{IK}^{\mathrm{L} / \mathrm{L}} \mathrm{Rag}^{-/-}$and $\mathrm{IK}^{+/+} \mathrm{Rag}^{-/-}$mice were reconstituted with 50-80 106 $\mathrm{pDC}$-depleted splenocytes from Foxp3-GFP mice and seven days later, mice were grafted with $5 \times 10^{5}$ TC-1 cells. Foxp3-GFP mice were used as control. (B) The tumor growth was followed until day 40 . The curves represent the means \pm SEM of the tumor diameter for each group and show the cumulative results from four experiments $(n=4$ to 5 mice per strain per experiment). Statistical analysis was performed by Wilcoxon test (ns: non- 
significant; $* * * p<0.001)$. (C, D) 25 days after the graft of tumor cells, cell suspensions were prepared from tumors and $\mathrm{CD}^{+} \mathrm{FoxP}^{+}$cells were analyzed by flow cytometry. (C) Frequency and (D) number of FoxP3 ${ }^{+}$cells among total $\mathrm{CD}^{+}{ }^{+} \mathrm{T}$ cells infiltrating the $\mathrm{TC}-1$ tumor. Results represent the cumulative data from four experiments $(n=2$ to 3 mice per strain per experiment) and each dot represents an individual mouse. Statistical analysis was performed by unpaired Student's $\mathrm{t}$ test (ns: non-significant; $* \mathrm{p}<0.05 ; * * \mathrm{p}<0.005$; $* * * * \mathrm{p}<0.0001)$ 


\section{FIGURE 1}

A
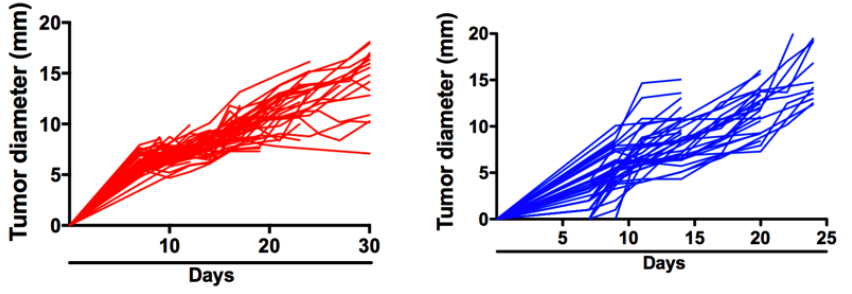

C
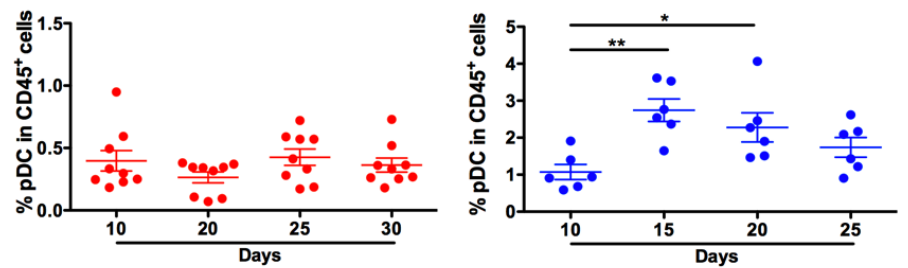

E

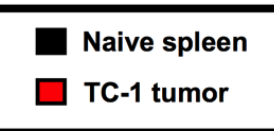

CD69
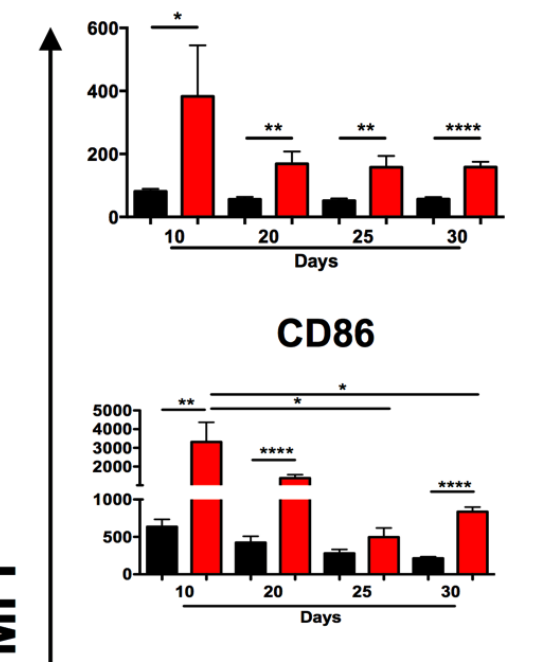

MHC-I

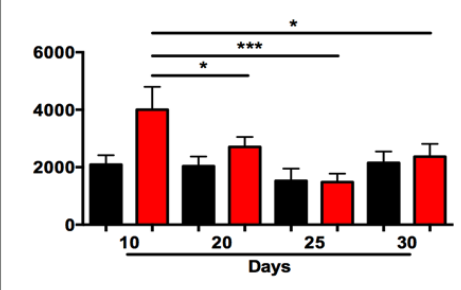

PDL-1

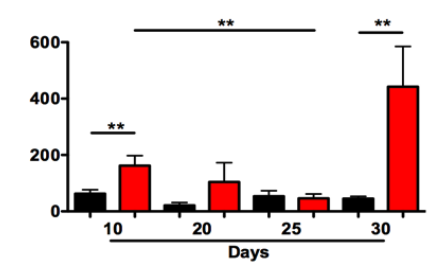

MHC-II

\section{B}
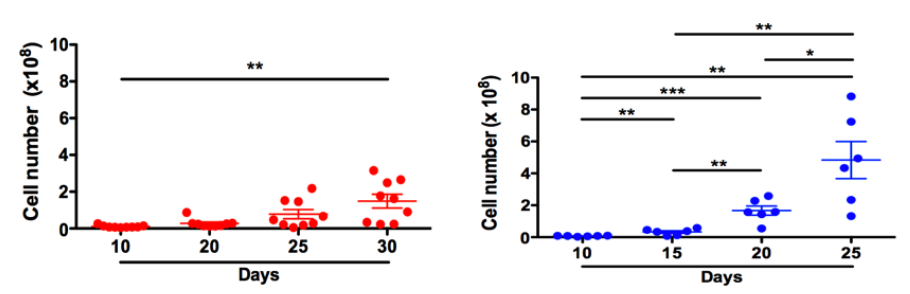

D
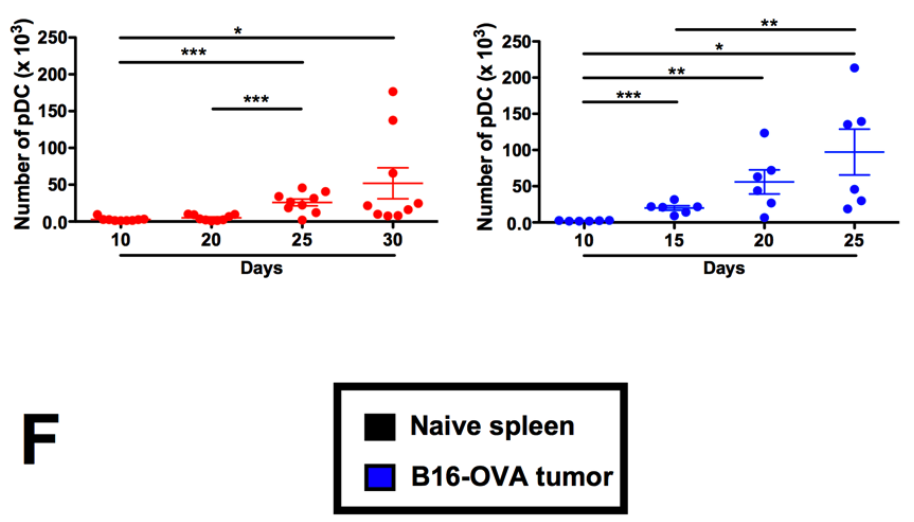

CD69

CD80
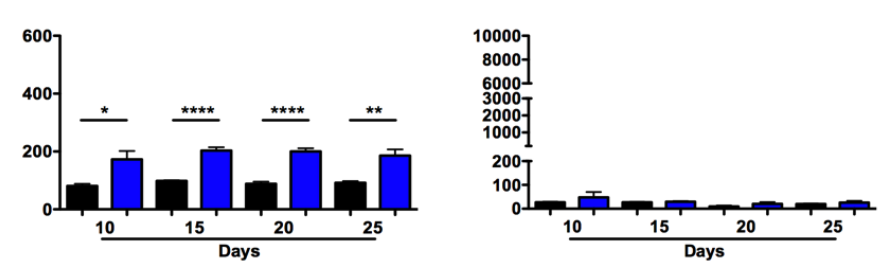

CD86

PDC-TREM
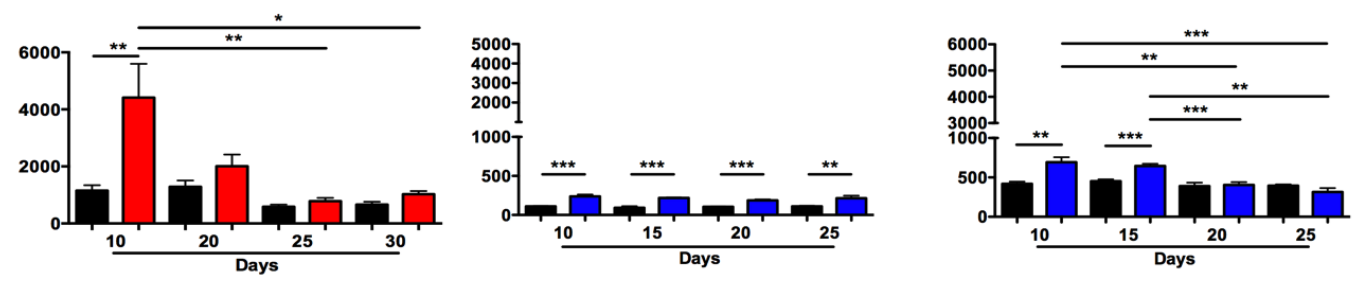

MHC-I
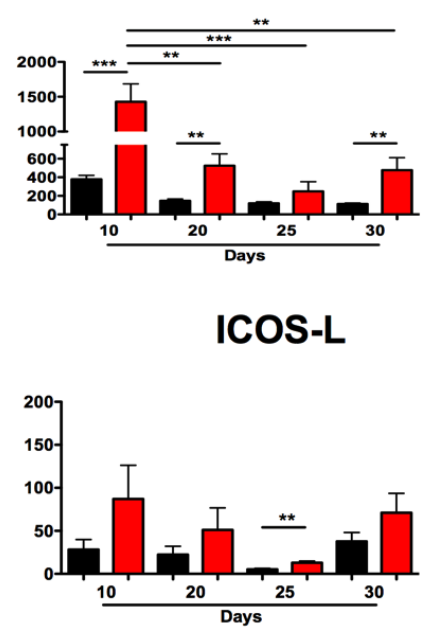

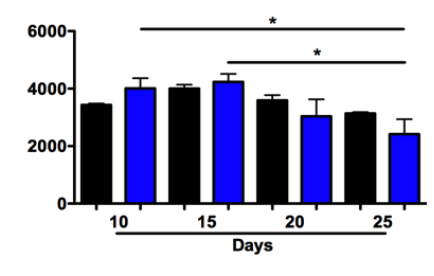

PDL-1

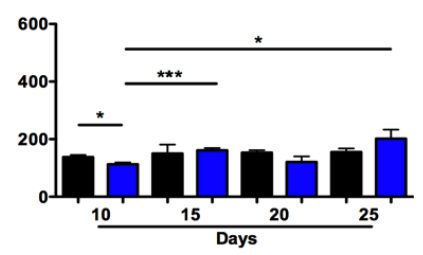

\section{MHC-II}
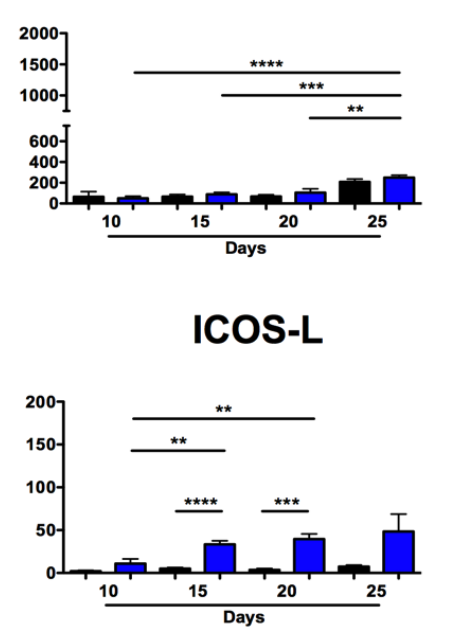


\section{FIGURE 2}

A

IFN- $\boldsymbol{\alpha}$
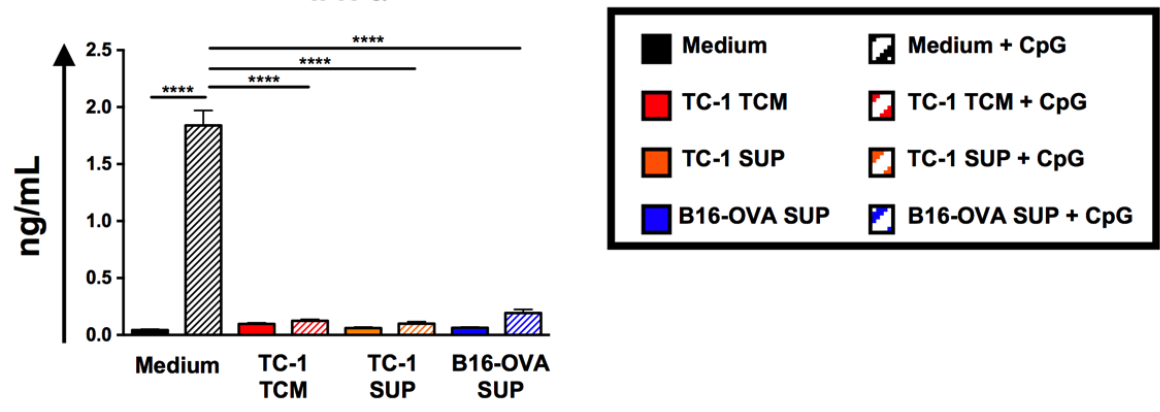

B
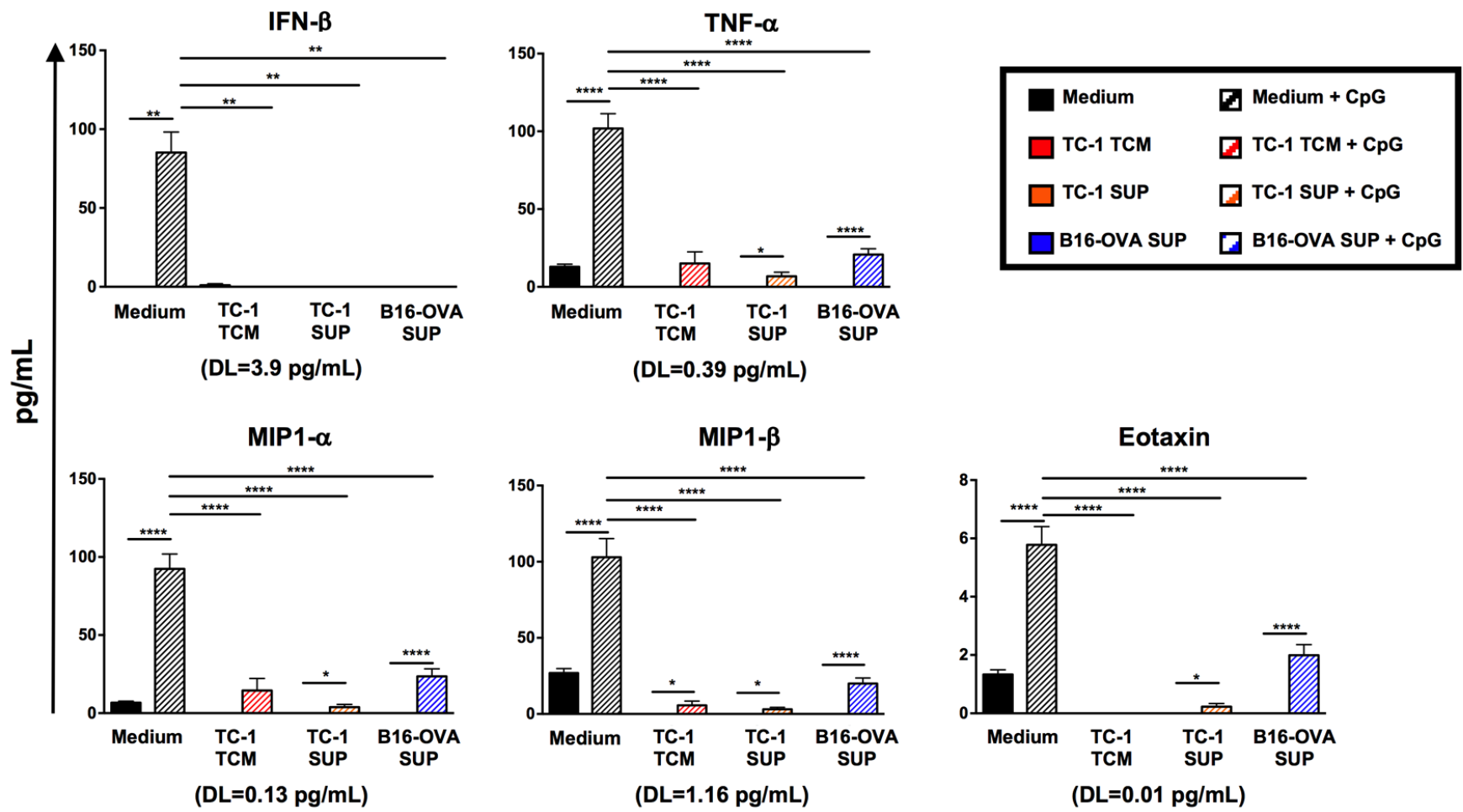

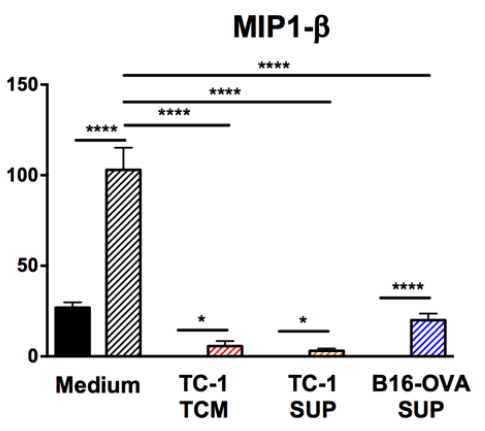

(DL=1.16 pg/mL)

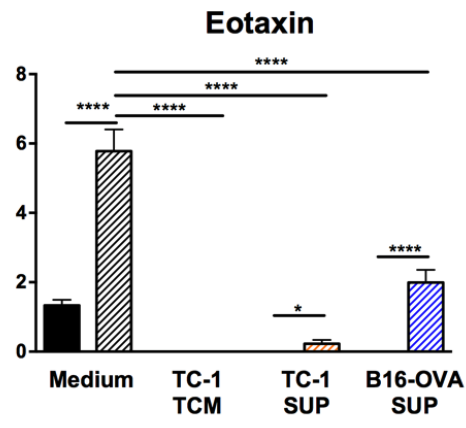

(DL=0.01 pg/mL)

C

\begin{tabular}{llll}
\hline Medium & $\square$ TC-1 TCM & $\square$ TC-1 SUP & $\square$ B16-OVA SUP \\
$\square$ Medium + CpG & $\square$ TC-1 TCM + CpG & $\square$ TC-1 SUP+CpG & $\square$ B16-OVA SUP + CpG
\end{tabular}

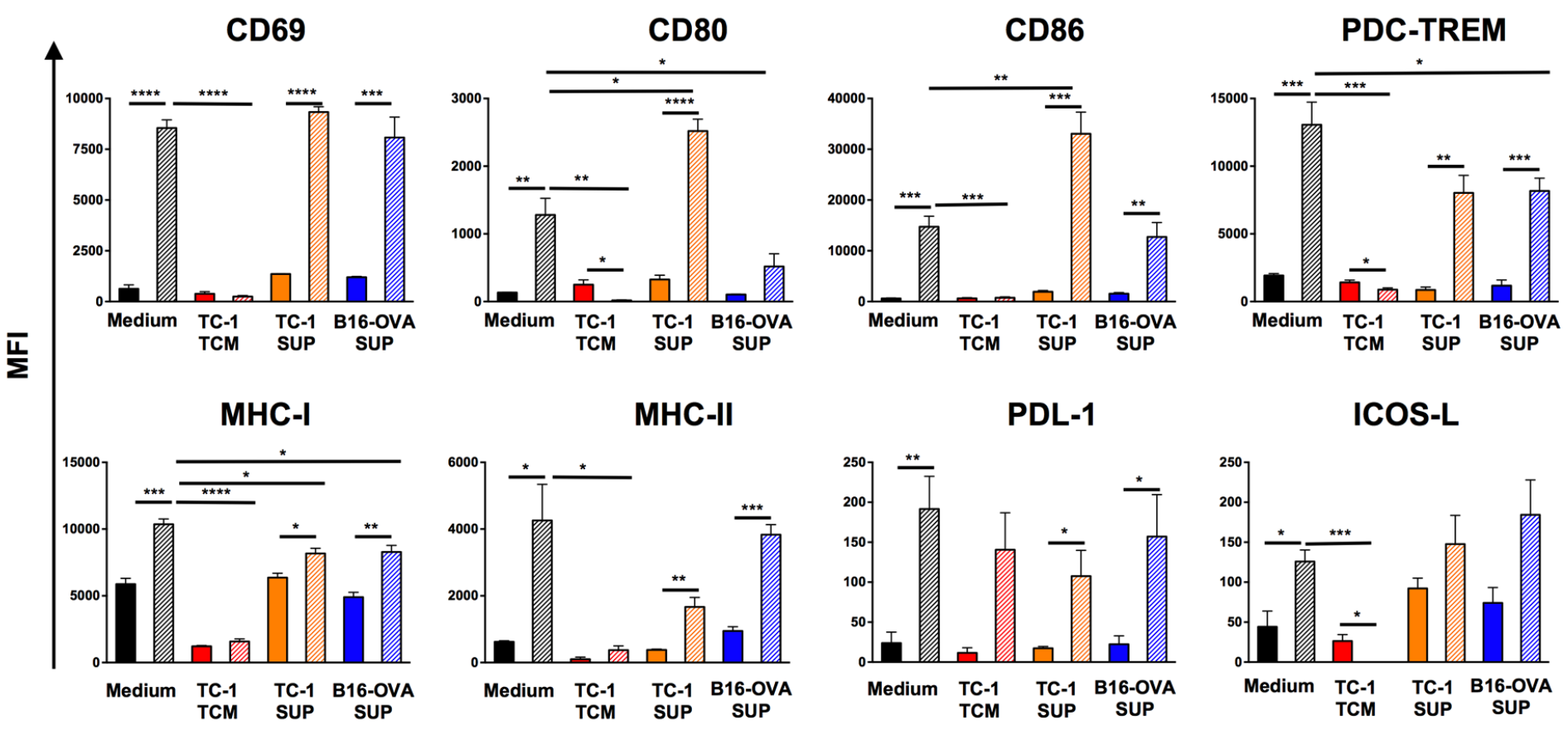


A

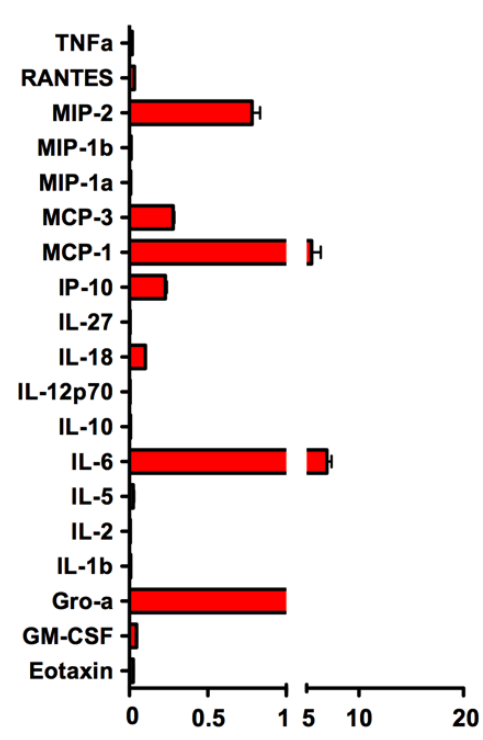

TC-1 SUP

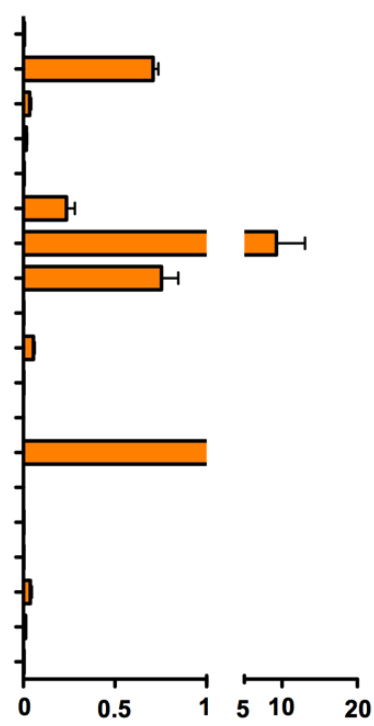

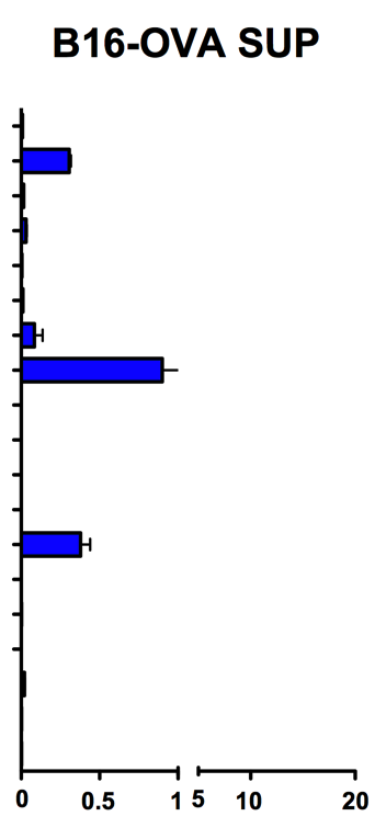

B
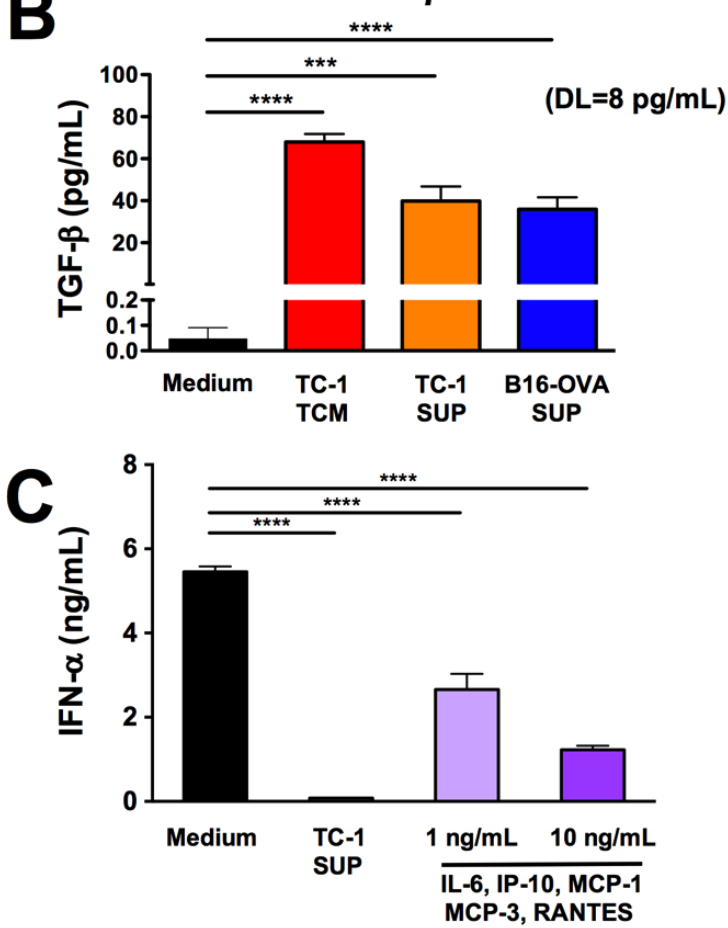
and TGF- $\beta$

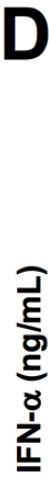

IL-6

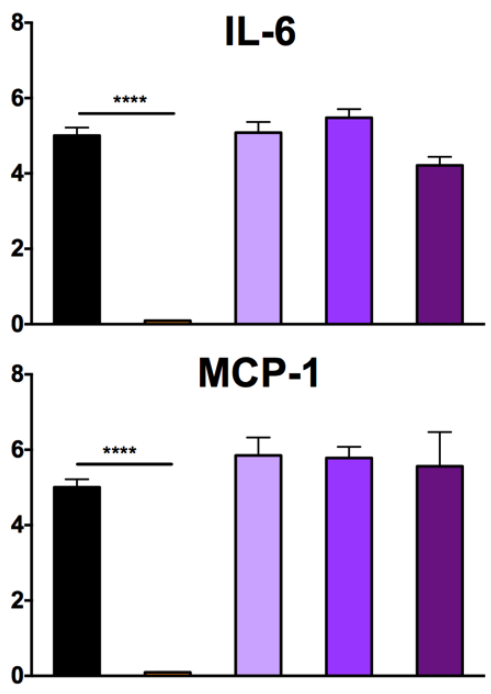

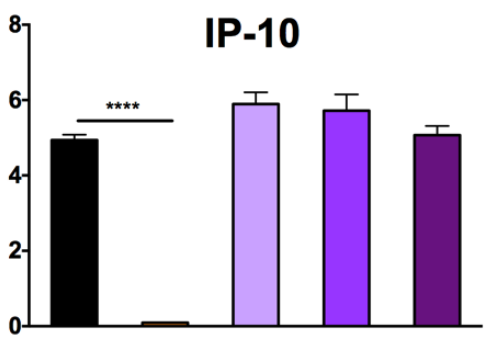

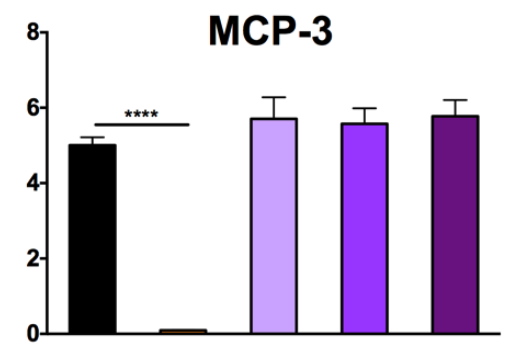

Medium

TC-1 SUP

$1 \mathrm{ng} / \mathrm{mL}$

$10 \mathrm{ng} / \mathrm{mL}$ cytokine/chemokine

$100 \mathrm{ng} / \mathrm{mL}$

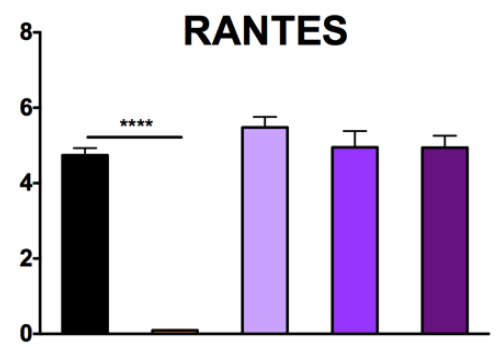

E

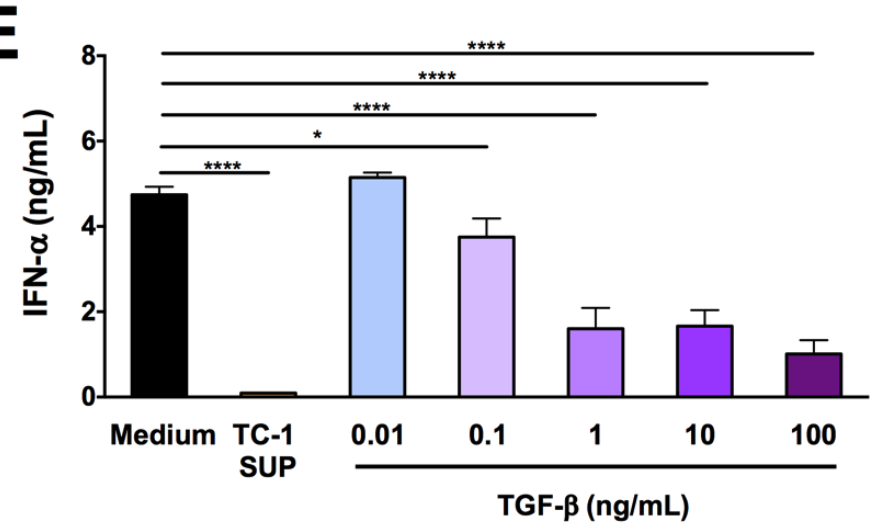

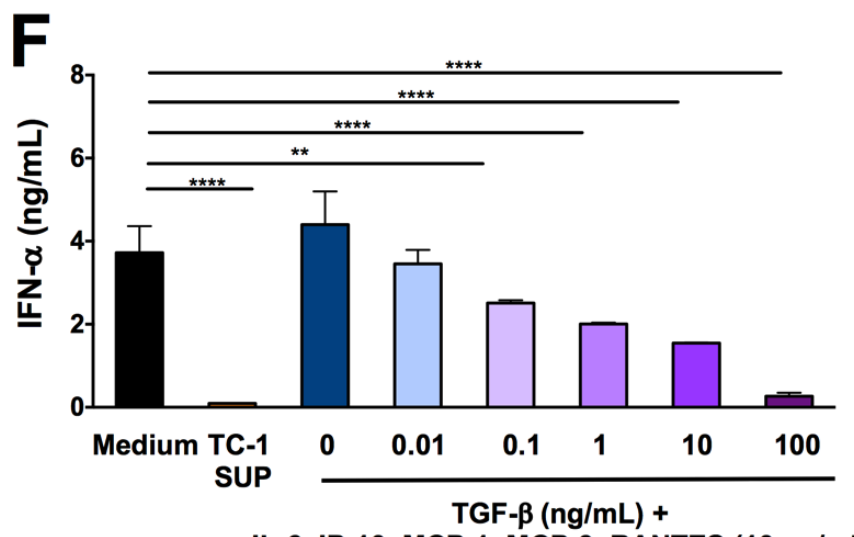

IL-6, IP-10, MCP-1, MCP-3, RANTES (10 ng/mL) 
FIGURE 4

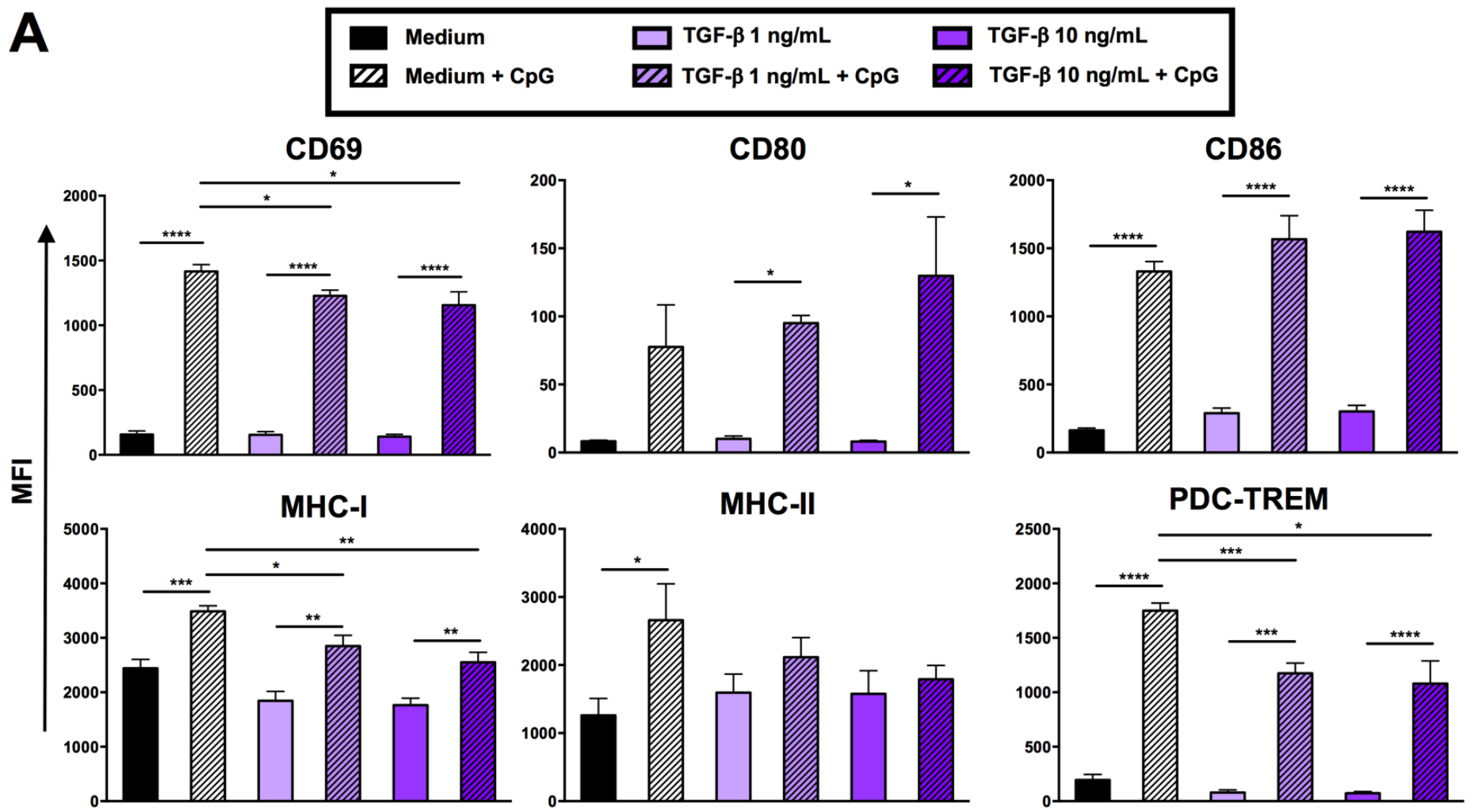

B
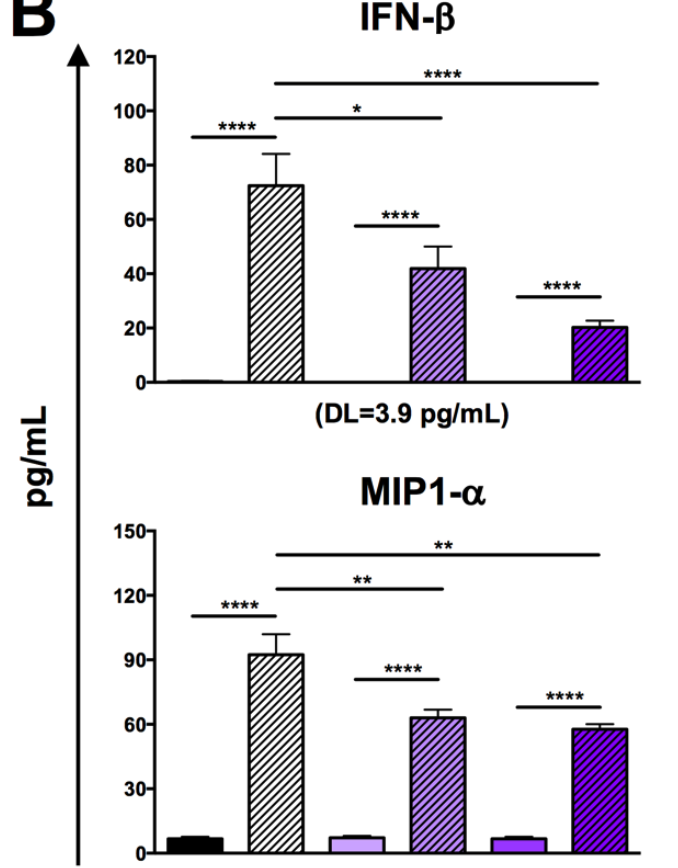

(DL=0.13 pg/mL)
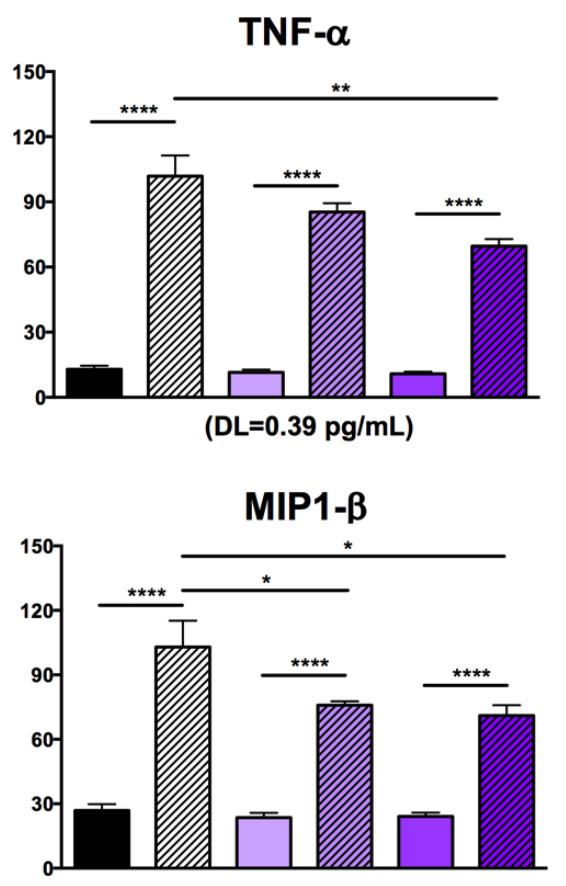

(DL=1.16 pg/mL)

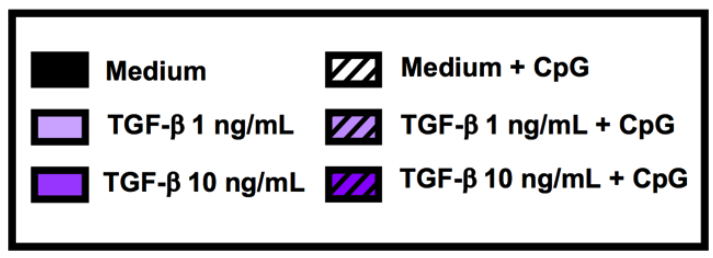

Eotaxin

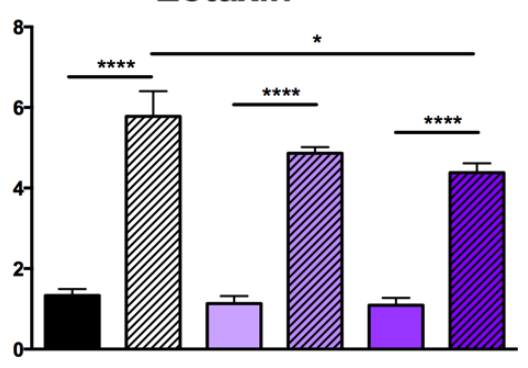

(DL=0.01 pg/mL) 


\section{FIGURE 5}

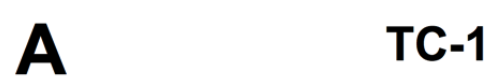

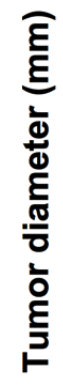

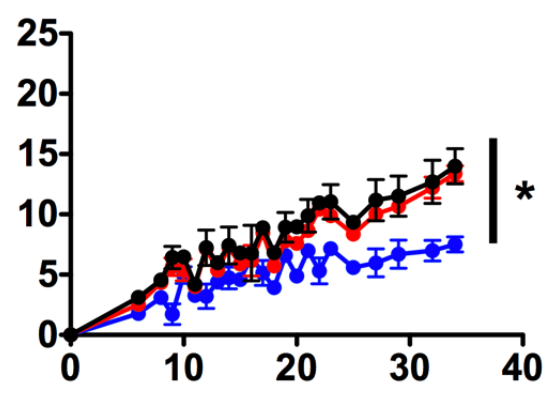

Days after injection
B

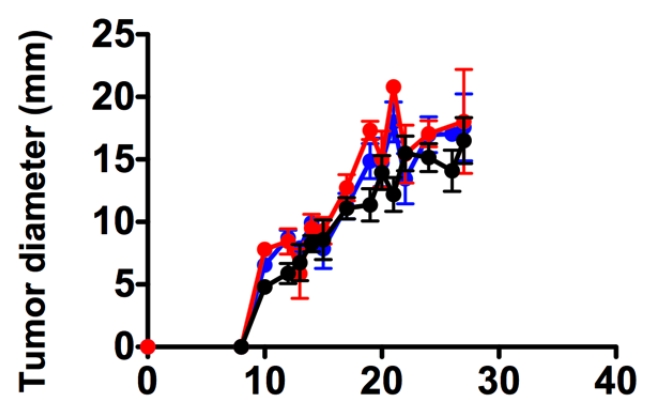

Days after injection

B16-OVA
C57BL/6

IKL/L Rag $^{-1 / 2}$

$\mathrm{IK}^{+/+}$Rag $^{-1+}$
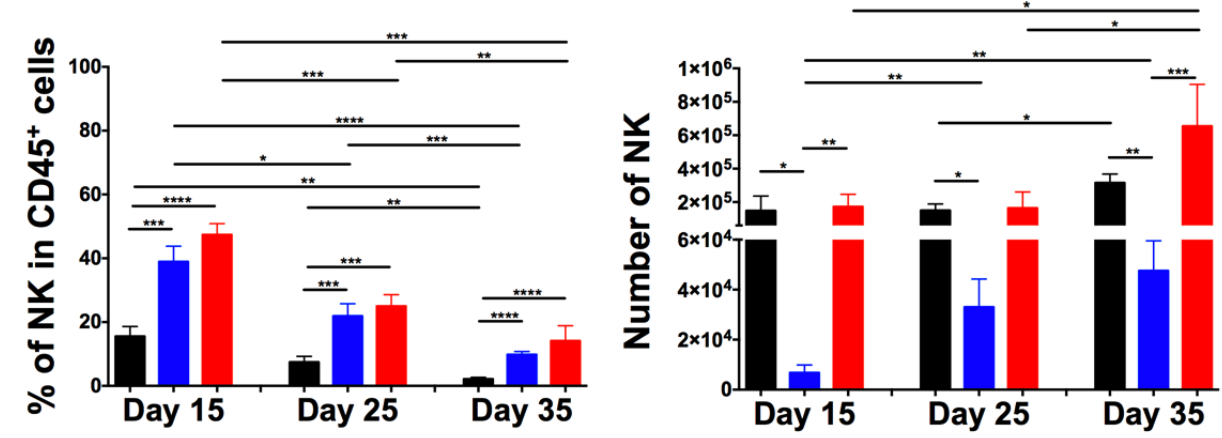

C57BL/6 $\square$ IKL/L Rag $^{-/-} \square$ IK $^{+/+}$Rag $^{-1 /}$

D
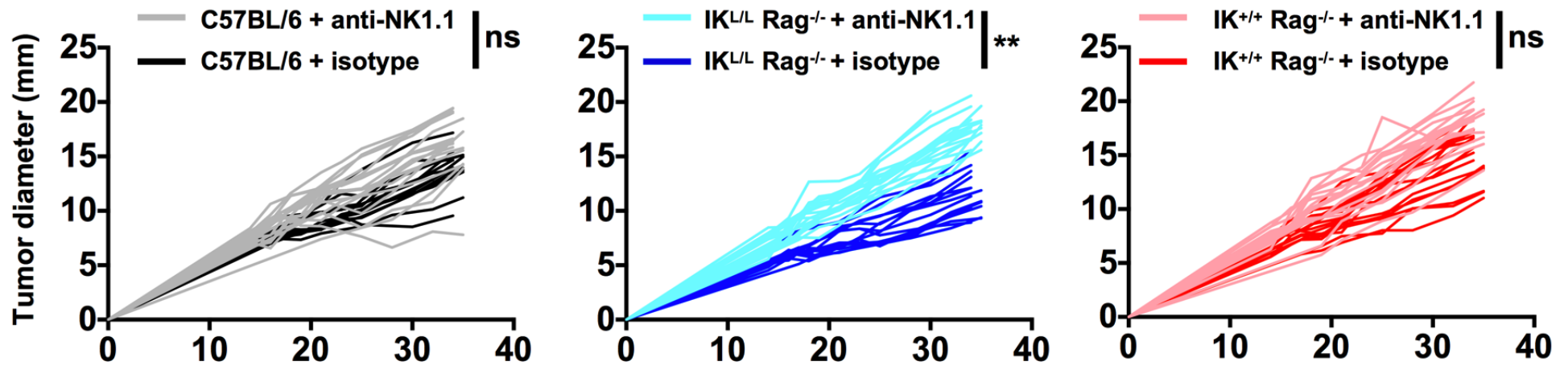

Days after injection

EE

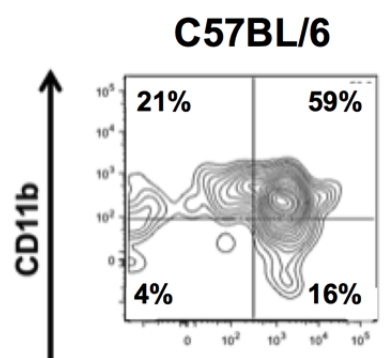

IK ${ }^{\mathrm{L} / \mathrm{L}} \mathbf{R a g}^{-/-} \quad \mathbf{I K}^{+/+} \mathbf{R a g}^{-/-}$
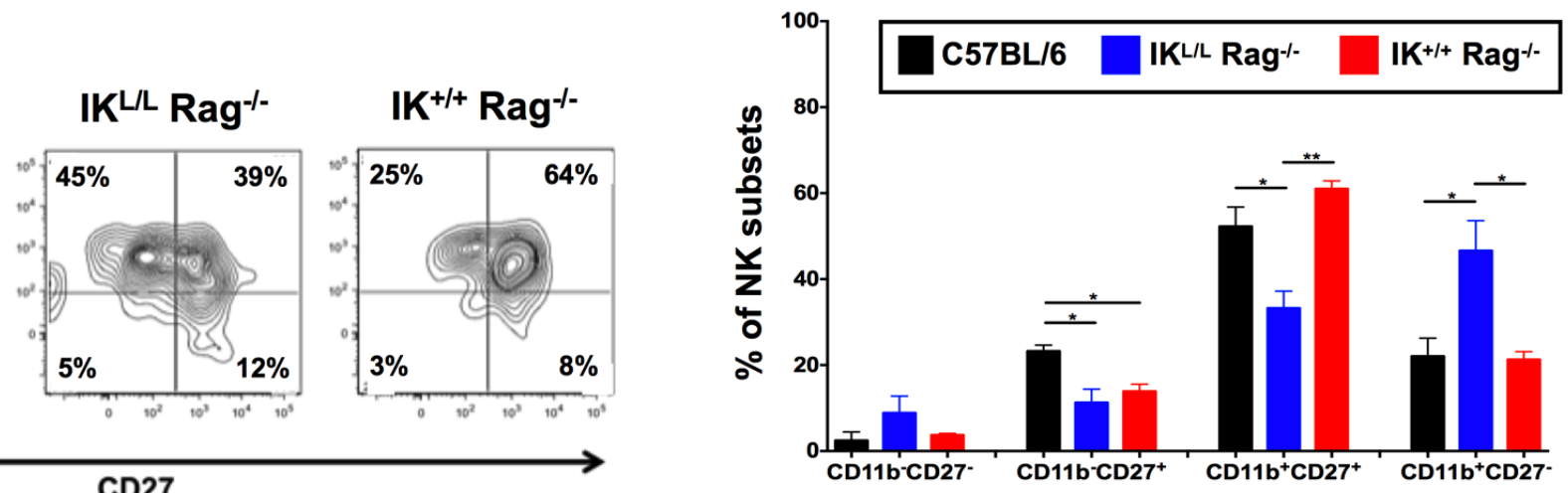

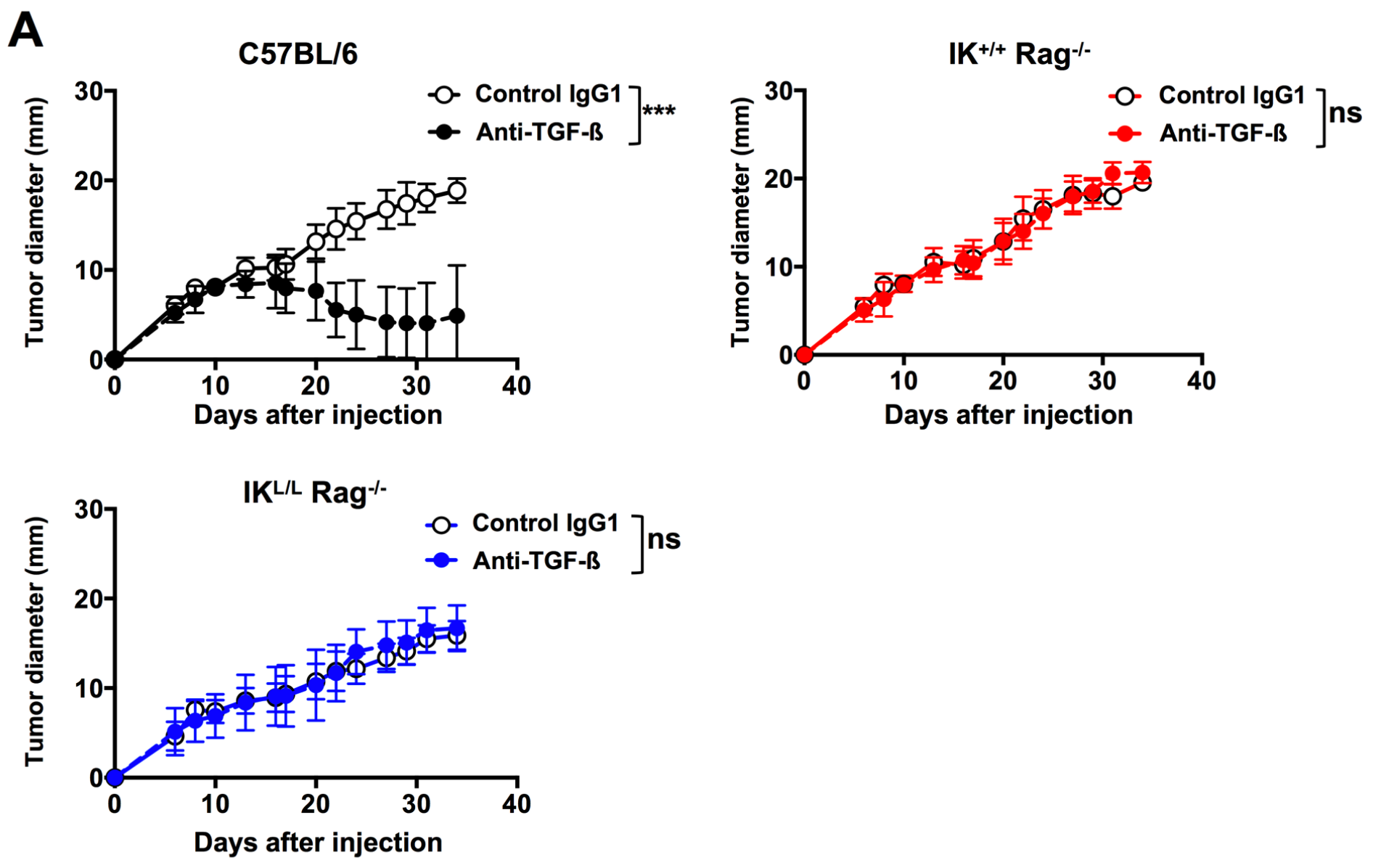

B
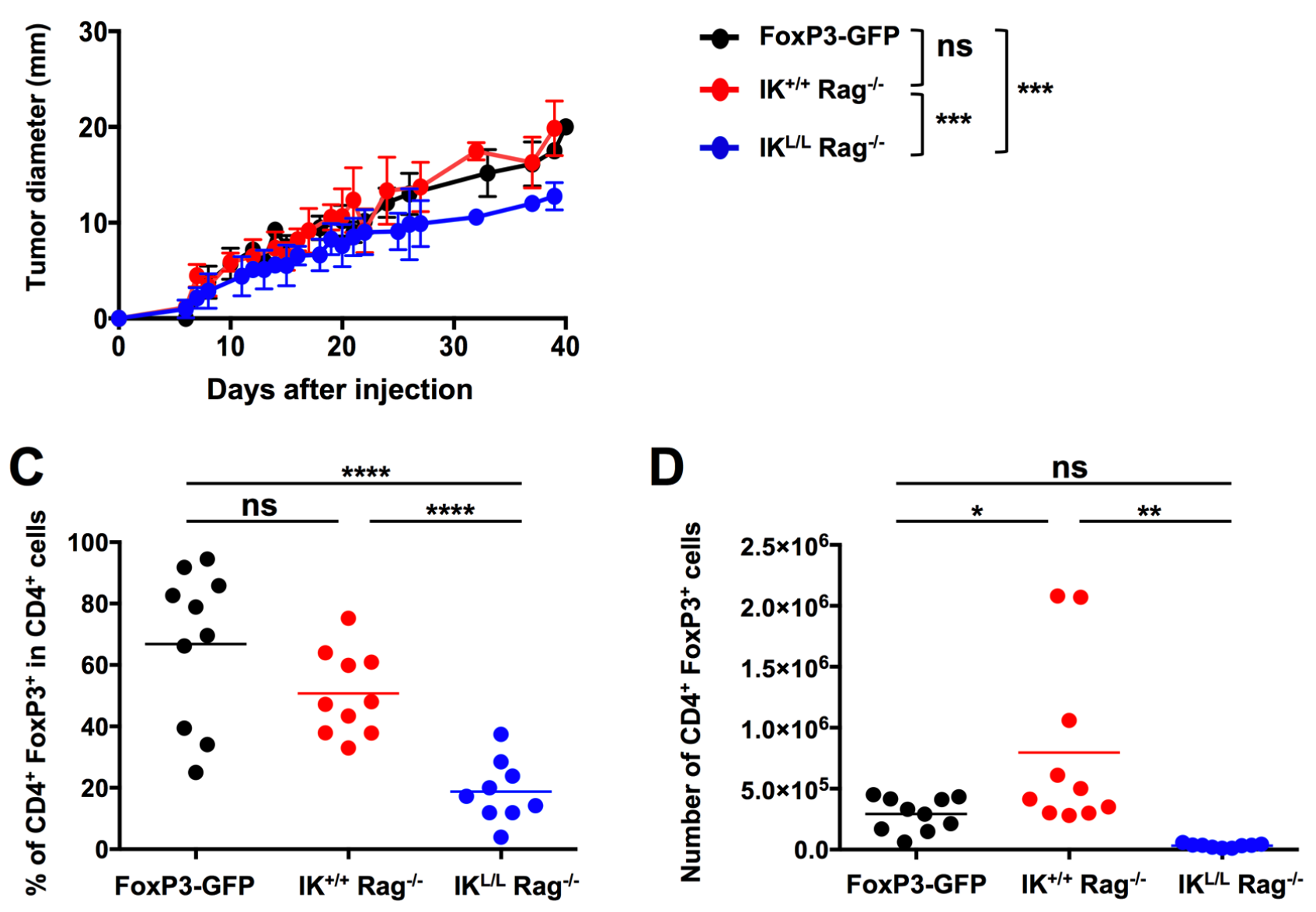


\section{Cancer Research}

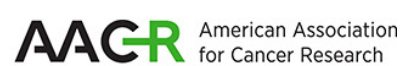

The Journal of Cancer Research (1916-1930) | The American Journal of Cancer (1931-1940)

\section{Tumor-derived TGF- $\beta$ alters the ability of plasmacytoid dendritic cells to respond to innate immune signaling}

Mariana Terra, Marine Oberkampf, Catherine Fayolle, et al.

Cancer Res Published OnlineFirst March 9, 2018.

\section{Updated version Access the most recent version of this article at:} doi:10.1158/0008-5472.CAN-17-2719

Supplementary Access the most recent supplemental material at:

Material http://cancerres.aacrjournals.org/content/suppl/2018/03/09/0008-5472.CAN-17-2719.DC1

Author Author manuscripts have been peer reviewed and accepted for publication but have not yet Manuscript been edited.

E-mail alerts Sign up to receive free email-alerts related to this article or journal.

Reprints and To order reprints of this article or to subscribe to the journal, contact the AACR Publications

Subscriptions Department at pubs@aacr.org.

Permissions To request permission to re-use all or part of this article, use this link http://cancerres.aacrjournals.org/content/early/2018/03/09/0008-5472.CAN-17-2719.

Click on "Request Permissions" which will take you to the Copyright Clearance Center's (CCC) Rightslink site. 